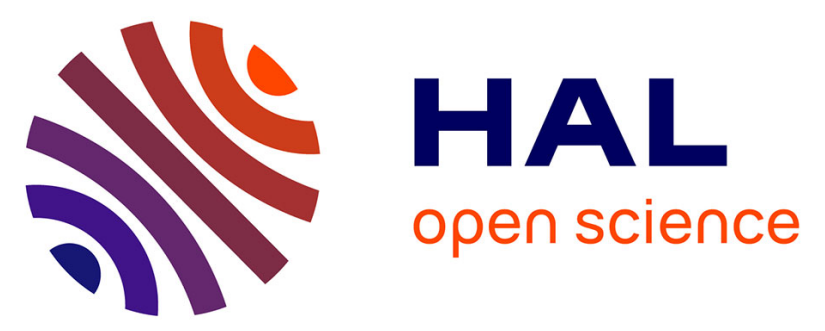

\title{
Processes and typology in Gilbert-type delta bottomset deposits based on outcrop examples in the Corinth Rift
}

Romain Rubi, Sébastien Rohais, Sylvie Bourquin, Isabelle Moretti, Guy

Desaubliaux

\section{- To cite this version:}

Romain Rubi, Sébastien Rohais, Sylvie Bourquin, Isabelle Moretti, Guy Desaubliaux. Processes and typology in Gilbert-type delta bottomset deposits based on outcrop examples in the Corinth Rift. Marine and Petroleum Geology, 2018, 92, pp.193-212. 10.1016/j.marpetgeo.2018.02.014 . hal02187477

\section{HAL Id: hal-02187477 \\ https: / hal-univ-pau.archives-ouvertes.fr/hal-02187477}

Submitted on 29 Jul 2019

HAL is a multi-disciplinary open access archive for the deposit and dissemination of scientific research documents, whether they are published or not. The documents may come from teaching and research institutions in France or abroad, or from public or private research centers.
L'archive ouverte pluridisciplinaire HAL, est destinée au dépôt et à la diffusion de documents scientifiques de niveau recherche, publiés ou non, émanant des établissements d'enseignement et de recherche français ou étrangers, des laboratoires publics ou privés.

\section{(2)(1) $\$$}

Distributed under a Creative Commons Attribution - NonCommercial - ShareAlikel 4.0 
Research paper

\title{
Processes and typology in Gilbert-type delta bottomset deposits based on outcrop examples in the Corinth Rift
}

\author{
Romain Rubi ${ }^{\mathrm{a}, \mathrm{b}, *}$, Sébastien Rohais ${ }^{\mathrm{c}}$, Sylvie Bourquin ${ }^{\mathrm{a}}$, Isabelle Moretti ${ }^{\mathrm{b}}$, Guy Desaubliaux ${ }^{\mathrm{b}}$ \\ a Univ Rennes, CNRS, Géosciences Rennes - UMR 6118, F-35000 Rennes, France \\ ${ }^{\mathrm{b}}$ Engie, 1 Place Samuel de Champlain, 92930, Paris La Défense Cedex, France \\ ${ }^{c}$ IFP Energies nouvelles - Géosciences Division, 1 et 4 avenue de Bois-Préau, 92852, Rueil-Malmaison Cedex, France
}

\section{A R T I C L E I N F O}

\section{Keywords:}

Facies association

Depositional architecture

Sequence stratigraphy

Hydraulic jump

Bypass

\begin{abstract}
A B S T R A C T
Middle Pleistocene Gilbert-type delta in the Gulf of Corinth, Greece, has been investigated combining field methods and photo acquisition by drone to generate a high-resolution 3D model. This study case can be used to document four different dynamics in Gilbert-type bottomset deposits, each one of which is characterized by a specific range of facies, facies associations and geometries: (1) the sandy-gravelly bottomset, (2) the erosionalbypass stage, (3) the fine-grained bottomset and (4) the massive-sandy bottomset. By comparing the typologies of the bottomset, we propose a conceptual model that predicts the occurrence of these four different bottomset stage dynamics depending on the stratigraphic context.

During highstand normal regression, the gravelly bottomset develops under subcritical flow. The supercritical flow undergoes a stationary hydraulic jump in the toeset due to the slope break. As a result, a low-relief channellevees system is formed in the bottomset. The channels are filled/reworked by backstepping conglomeratic lenses interbedded with silty concave-up and concave-down levees. During normal regression, the foreset beds are steeper than during previous stage and scoured in the upper part. In the bottomset, significant erosion recording sediment bypass downstream toward the pro-delta can be observed. During lowstand normal regression, a starved fine silt to shale bottomset onlaps onto the major erosional surface. The bulk of the coarsegrained sediments is stored in the delta topset and foreset. During the transgressive to highstand stage, the former topset and foreset are eroded by high-density turbidity currents and massive-sandy turbidites are deposited in the bottomset, which onlap onto the foreset beds and form a slope apron geometry in the delta toe.

The stratigraphic model improves the prediction for the sand distribution within the various parts of the bottomset. This approach is particularly relevant for clastic depositional systems with high sediment discharge and a high accommodation rate.
\end{abstract}

\section{Introduction}

The transfer of sediment from the catchment area to the deeper marine environments is crucial to better constrain the nature and architecture of sediments that control potential mineral resources (Sømme et al., 2009). The processes responsible for transporting and bypassing large volumes of sediment from the shoreline to the deep sea, such as submarine gravity flows, are a key factor to characterize and model the transfer of sediment (Nemec, 1990; Stevenson et al., 2015). Nevertheless, the bypass phenomenon has not been systematically described and integrated into a sequence stratigraphic framework. It is often difficult, if not impossible, to characterize the entire depositional profile, including the facies description and associated architectural elements from the sedimentary source to the most distal setting, with a detailed characterization of the sedimentary processes integrated within a sequence stratigraphic framework in outcrops. To address this issue, we focus on a Gilbert-type delta, which has a short-length depositional profile that allows to observe the entire depositional system from the sediment source to the deep basin (Fig. 1a).

Gilbert-type deltas, first described from Lake Bonneville beds, occur in front of river mouths in deep lacustrine (Gilbert, 1885) or marine basins (Postma and Roep, 1985) and are commonly linked with tectonically active settings (Gawthorpe and Colella, 1990; Dart et al., 1994; Dorsey et al., 1995). They have an internal tripartite architecture: topset, foreset and bottomset (Fig. 1a and b).

The geometries, sedimentary processes and stratigraphic architectures in topsets and foresets are well known (e.g. Prior, 1981; Lowe, 1982; Postma, 1984a, b; Bornhold and Prior, 1988; Massari and Colella,

\footnotetext{
* Corresponding author. Géosciences Rennes, UMR CNRS 6118, OSUR, Université Rennes 1, 35042, Rennes Cedex, France.

E-mail address: romain.rubi@univ-rennes1.fr (R. Rubi).
} 


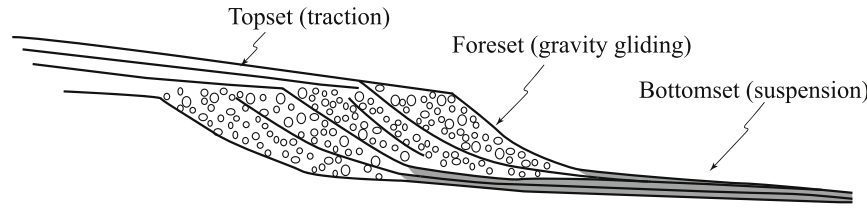

(a) Gilbert-Type Delta (Gilbert,1885)

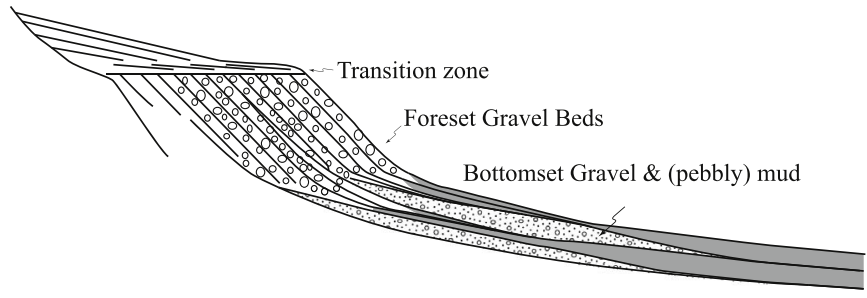

(b) Modified Gilbert-Type Delta (Postma and Roep, 1984)

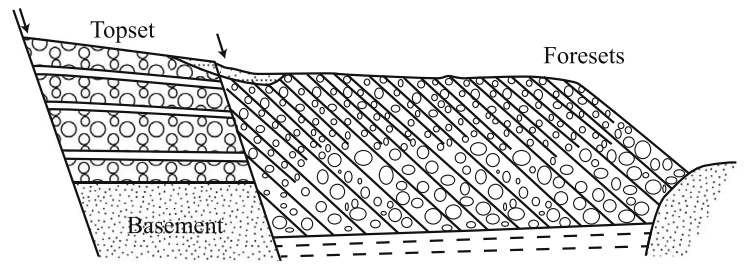

(c) Trapezoidal Fan Delta (Poulimenos et al., 1993)

Fig. 1. a: Gilbert-type delta cross-sections from Gilbert (1885); b: Modified Gilbert-type delta from Postma and Roep (1985); c: Trapezoidal fan delta from Poulimenos et al. (1993).

1988; Kostaschuk and McCann, 1989; Nemec, 1990; Horton and Schmitt, 1996; Massari, 1996; Breda et al., 2007; Rohais et al., 2008). Conversely, toesets and bottomsets are poorly charaterized and constrained. The toeset forms the tangential transition from a foreset to a bottomset, and presents a large scale clinoform that has already been studied (Breda et al., 2007; Rohais et al., 2008; Gobo et al., 2014).

Three bottomsets typologies are commonly defined. Firstly, Gilbert (1885) described fine-grained, shale to silt bottomset deposits, interpreted as primarily recording a decantation process (Fig. 1a). This means that all the coarse-grained sediments are assumed to be stored in the delta or upstream. Secondly, Postma (1984a, b) and Postma and Roep (1985) illustrated the occurrence of pebbles in the bottomset, called bottomset-modified Gilbert-type delta (Fig. 1b), produced by major delta front failures. The conglomerates are limited in the bottomset area and could not reach the distal part of the basin. Thirdly, Poulimenos et al. (1993) introduced the trapezoidal fan delta (Fig. 1c), which is a Gilbert-type delta characterized by the lack of bottomset deposits. It can either be explained by a sediment storage upstream from the bottomset area or by a sediment bypass in the bottomset area (Doutsos and Poulimenos, 1992). Under this last hypothesis it may possible to export coarse-grained sediments trough the basin. Nevertheless, the presence of both a turbiditic system as well as conglomeratic beds and channels described by Ferentinos et al. (1988) and Rohais et al. (2008) in the Corinth rift cannot be properly explained by any of these three models (Fig. 1).

The purpose of this paper is to present for the Ilias Gilbert-type delta, exposed on the southern margin of the Gulf of Corinth: (1) a sedimentological description of the foreset-toeset-bottomset, (2) their geometries and related processes, in order to finally establish (3) a sedimentological model integrated within a sequence stratigraphic framework.

We propose a comparison with studies based on the same outcrop (Rohais et al., 2008; Gobo et al., 2014) and with previous Gilbert-type delta models (Gilbert, 1885; Postma and Roep, 1985; Poulimenos et al.,
1993) to challenge them within a stratigraphic context. Finally, an innovative model is proposed to document Gilbert-type delta typology stratigraphic evolution and sediment processes. Reservoir and seal occurrences in the distal basin axis could then be better predicted, especially in active tectonic settings such as rifts in their early phases.

\section{Geological setting}

The present investigations are based on the Ilias Gilbert-type delta, located on the southern coast of the Gulf of Corinth, Greece (Fig. 2a). The Gulf of Corinth is an active east-west graben with currently very fast north-south opening rates at $0.5 \mathrm{~cm} / \mathrm{yr}$ eastward and $1.5 \mathrm{~cm} / \mathrm{yr}$ westward (Tselentis and Makropoulos, 1986; Billiris et al., 1991; Clarke et al., 1997; Briole et al., 2000). The extension is generally interpreted as the result of a back-arc extension within the frame of the East Mediterranean subduction (Fig. 2a, e, g. Rohais and Moretti, 2017). As the gulf is also located at the tip of the North Anatolian Fault (NAF), the observed changes in subsidence and uplift are generally interpreted in relation with the propagation of the NAF. However the interactions between the two major features, subduction and NAF propagation, are complex and are still being discussed (e.g. Moretti et al., 2003, and references within). The thickness of the syn-rift sediments reaches up to $3 \mathrm{~km}$ and the current maximum water depth is $860 \mathrm{~m}$ (Clément et al., 2004). Extension started at the end of the Miocene in the Aegean Sea (Jolivet et al., 1994) as well as in the Corinth Rift (Papanikolaou et al., 2009) and affected an area much larger than the current gulf. The southern coast has been uplifted from ca. $0.8 \mathrm{Myr}$ providing outcrops of early syn-rift sediments along a proximal to distal profile (e.g. Rohais et al., 2007; Rohais and Moretti, 2017). The uplift rate reached $1.5 \mathrm{~mm} /$ yr since the late middle Pleistocene (Stewart and Vita-Finzi, 1996; Stewart, 1996). The pre-rift sequence, referred to hereafter as the prerift basement, consists of a stack of Mesozoic and early Paleogene northsouth oriented thrust sheets. The carbonate-dominated deposits have been highly structured by the Hellenic compressive phases.

The models for the stratigraphic evolution of the Gulf of Corinth available in the literature are mainly based on seismic interpretations; nevertheless, there is no deep well to constrain the facies, the thicknesses or the timing of sedimentation of the offshore deposits. In consequence, the evolution of the Gulf of Corinth is still being debated and was recently reviewed (Nixon et al., 2016; Rohais and Moretti, 2017). From outcrops the evolution has been subdivided into three phases (Fig. 2b, c, Rohais et al., 2007): 1) the Lower group, composed of continental to shallow fresh or brackish lacustrine deposits with a subsidence compensated by sedimentation; 2) the Middle group, which recorded a major structural reorganization and an increase in bathymetry with massive turbiditic deposits; during the late Middle group, Gilbert-type deltas developed on active normal faults and followed the northward fault migration; and 3) the Upper group, characterized by stepped terraces and slope breccias onshore in relation with the southern margin uplift and the rapid subsidence of the basin axis.

The Mavro-Ilias-Evrostini Gilbert-type delta (GTD) system is located between the cities of Derveni and Xylokastro (Fig. 2b). It developed during the late Middle group rifting phase (Fig. 2c) and was then fully exhumed during the recent Quaternary uplift of the southern margin. The stratigraphic architecture established by Rohais et al. $(2007,2008)$ considered that the Mavro GTD progrades from Mount Mavro and progressively passes downstream to the Ilias GTD. The Evrostini GTD developed on top of the Ilias GTD. The Ilias GTD (ca. $4 \mathrm{~km}$ long and ca. $300 \mathrm{~m}$ thick) spectacularly crops out along the Derveni River where the geometrical relationship from the foreset to bottomset and the associated turbidite systems can be studied in detail (Fig. 2d).

\section{Dataset and methodology}

This study is based on outcrop observations with conventional field methods and via abseiling: detailed logging scale 1/50e, facies 

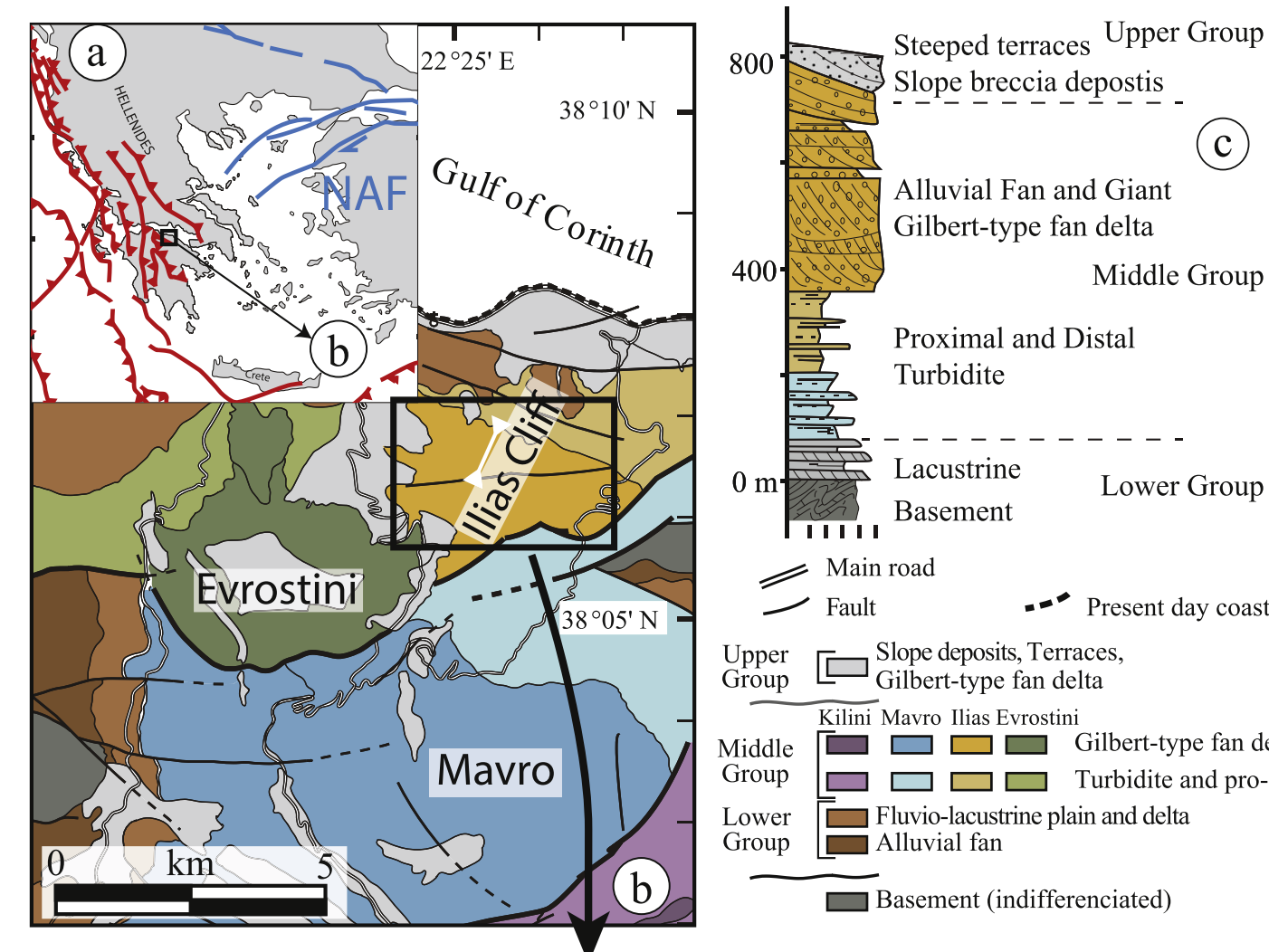

Slope breccia depostis

Alluvial Fan and Giant

Gilbert-type fan delta

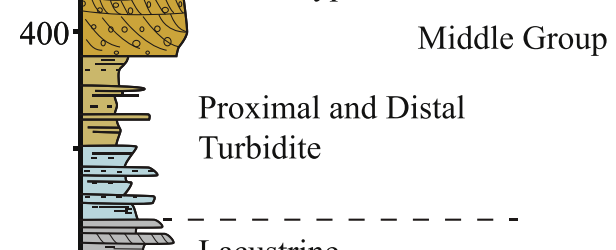

$0 \mathrm{~m}$ Lower Group

$$
\text { Main road } \quad \text { Fault } \quad \text { Present day coastline }
$$

Upper Slope deposits, Terraces,

Group $\square$ Gilbert-type fan delta

Middle $\square \square \square \square$ Gilbert-type fan delta

Group $\square \square \square \square$ Turbidite and pro-delta

Lower $\square$ Fluvio-lacustrine plain and delta

Group Alluvial fan

$\square$ Basement (indifferenciated)
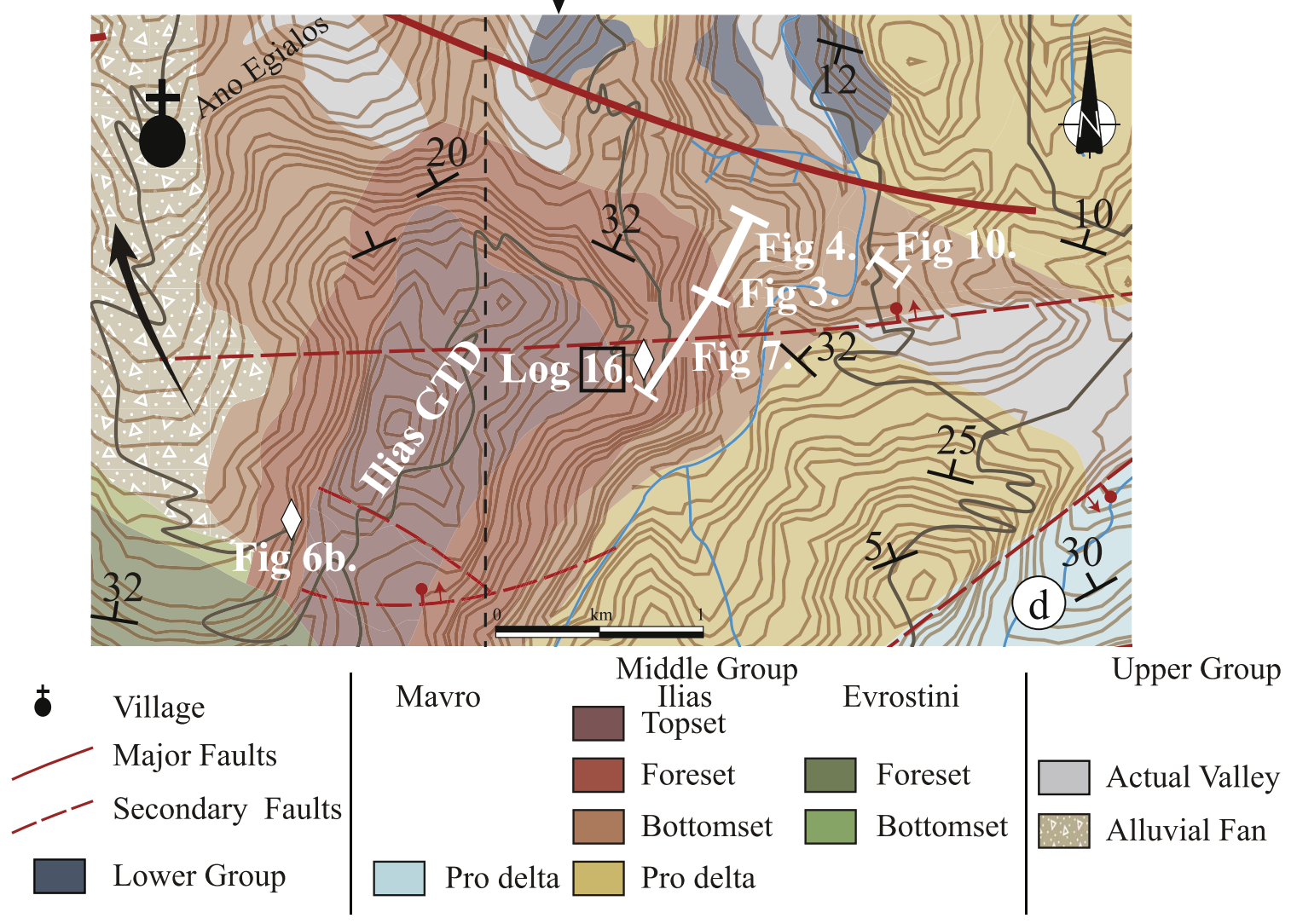

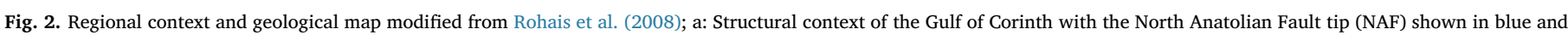

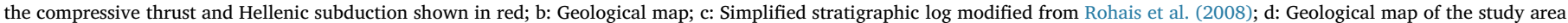
with position of the panoramas and log. (For interpretation of the references to colour in this figure legend, the reader is referred to the Web version of this article.) 

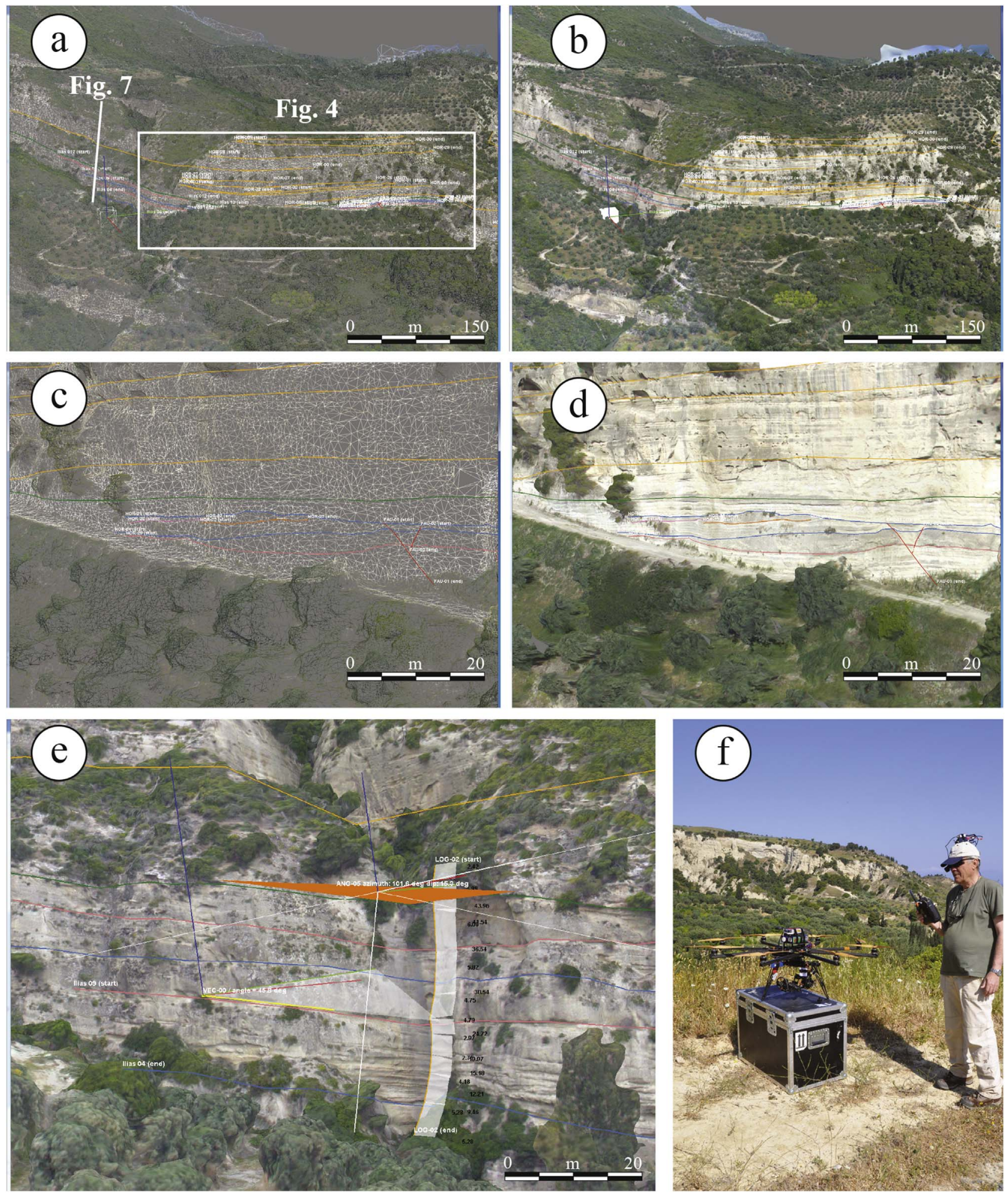

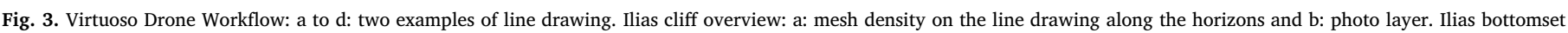

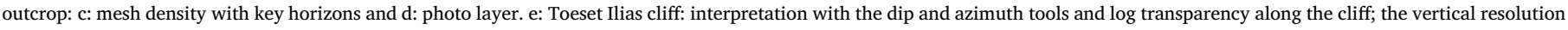
is around $5 \mathrm{~cm}$ in this area; f: photo of the drone and the camera pilot, a live video is displayed on a screen shown in the binoculars. See location in Fig. 2.

description and facies associations, line-drawing on photomosaics and log correlations. Additionally, a 3D outcrop photogrammetric model has been carried out to generate a more accurate line drawing and architectural element analysis. Photo acquisitions by drone and model processing were performed with the support of IFPEN (Schmitz et al., 2014). Twelve flights resulted in the acquisition of more than 2000 georeferenced images. A specialist software (Virtuoso) designed by IFPEN was used to manage the layering visualization and field data integration. The layers are displayed according to the scale observation (Fig. 3a-d); the various levels of the wireframe are dependent on the zoom (Fig. 3a, c). Virtuoso was then used to perform the 3D correlation and to take measurements on the modelled geometries (dip, surface, 


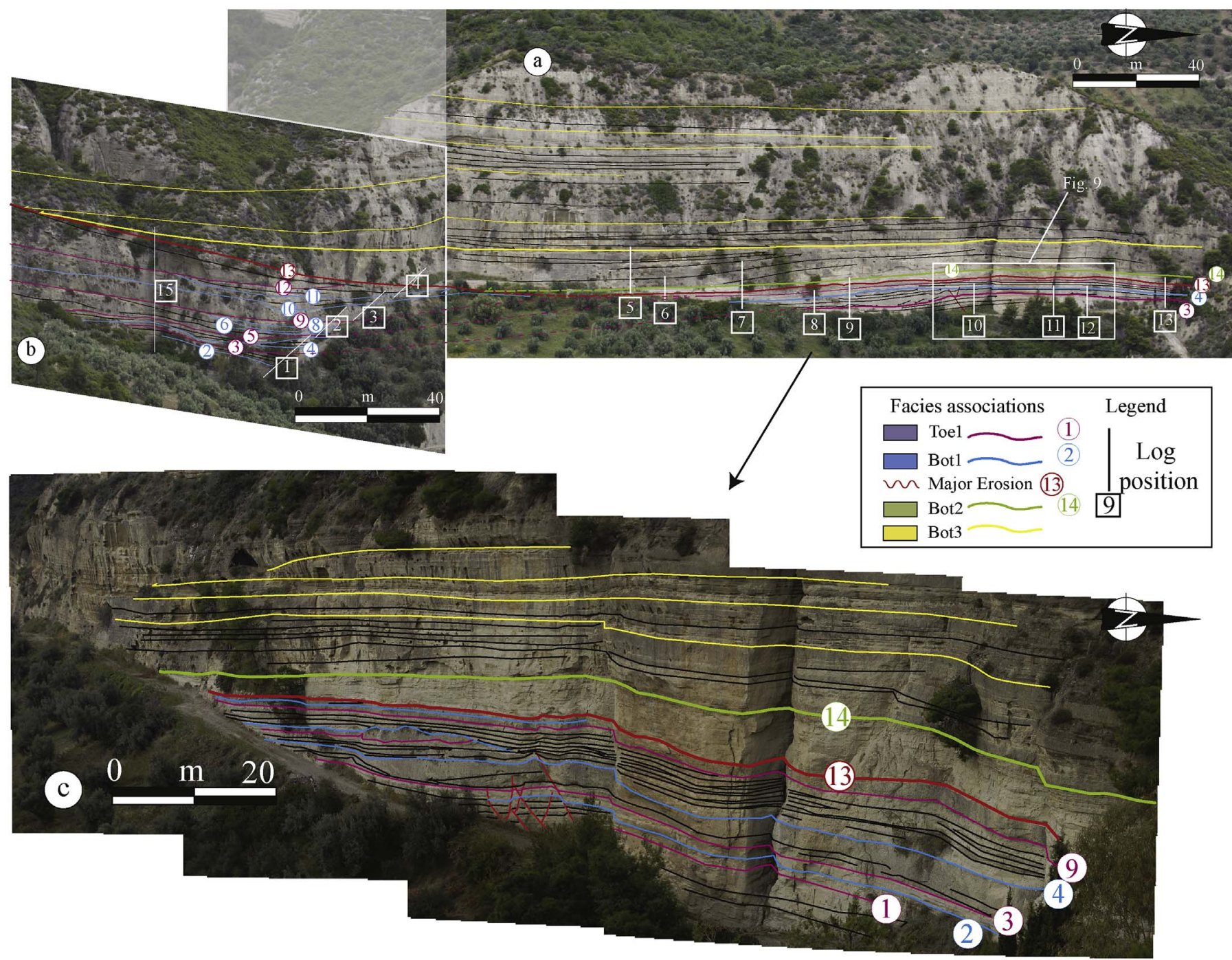

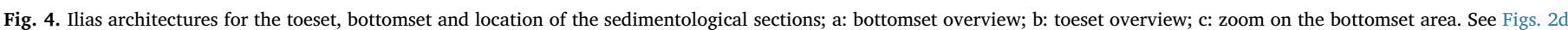
and $3 \mathrm{a}$ for the location.

length and vector; see Fig. 3e).

\section{Facies and depositional model}

The middle part of Ilias cliff shows the downstream transition from the foreset through the intermediate toeset to the distal bottomset in less than $1 \mathrm{~km}$ (Fig. 4). The foreset-bottomset geometry indicates a bathymetry that was more than $400 \mathrm{~m}$ deep. The main units have been identified based on their facies, facies associations, internal geometries and the relationship with their bounding surfaces (Fig. 4).

The facies description of the Ilias GTD (Table 1) is based on 16 detailed sedimentological sections; each facies is described, interpreted and classified from the coarsest (G1) to finest (F3) grains. From the foreset to the bottomset, the facies are gathered into six facies associations: 1) foreset; 2) modified foreset; 3) toeset; 4) sandy-gravelly bottomset; 5) fine-grained bottomset and 6) massive-sandy bottomset deposits. The results are presented from the foreset to the bottomset.

\subsection{Foreset}

\subsubsection{Foreset facies association: For1}

Description (i.e. G1, G2, F3; Table 1; Figs. $5 a$ and 6 a): The foreset facies association (For1) consists of two sub-facies associations: clast-to matrix-supported pebbly sandstones and conglomerates (For1a) and shales (For1b). Both For1a and For1b are well-bedded with beds dipping from $15^{\circ}$ to $20^{\circ}$.

The sub-facies association Forla is composed of an alternation of heterolithic pebbly sandstones and matrix-to clast-supported conglomerates (facies G1, G2) organized in 1-10 m thick packages (Fig. 5a). The G1 and G2 facies may reach up to $1-5 \mathrm{~m}$ in thickness (Fig. 5a, top of Fig. $6 \mathrm{~b})$. Clasts are generally sub-rounded to rounded. The massive facies G1 is matrix-to clast-supported with common openwork. Facies G2 corresponds to coarse-grained sand matrix-supported and cobble to pebble conglomerates displaying a crude fining-up feature. The top and bottom of the beds are continuous and extend up to several hundred metres in length.

The sub-facies association For $1 \mathrm{~b}$ is made up of $1-5 \mathrm{~cm}$ thick shale beds (F3) without floating clasts draping the $15^{\circ}$ to $20^{\circ}$ dipping foresets with a total thickness of $50 \mathrm{~cm}$ (Fig. 5a).

Interpretation: Massive clast-supported conglomeratic beds (G1) are interpreted as the result of a mass freezing and/or debris flow deposits (Lowe, 1982; Postma and Roep, 1985; Colella et al., 1987; Prior and Bornhold, 1988; Nemec, 1990; Mulder and Alexander, 2001). The matrix-rich foreset deposits (G2) are interpreted as the result of hyperconcentrated density flows (sensu Mulder and Alexander, 2001). Debris flows and en masse depositions are in accordance with the original description of Gilbert (1885) to maintain the angle of repose of this coarse-grained material on the slope of the delta. 
Table 1

Transition from the foreset to the bottomset: facies description and interpretation in terms of depositional process.

\begin{tabular}{|c|c|c|c|c|c|c|c|c|c|c|}
\hline \multirow[b]{2}{*}{ Schema } & \multirow[b]{2}{*}{ Name } & \multicolumn{4}{|c|}{$\begin{array}{l}\text { Main characteristics of the sedimentary facies and their interpretation in terms of depositional process: } \\
\text { Transition Foreset to Bottomset }\end{array}$} & \multicolumn{5}{|c|}{ Facies Association } \\
\hline & & Facies Name & Description & Bed Geometry & $\begin{array}{l}\text { Processus } \\
\text { Classification from Mulder } \\
\text { \& Alexander (2000) }\end{array}$ & 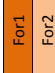 & 竎 & 焉 & 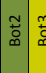 & 苍 \\
\hline & G1 & $\begin{array}{l}\text { Well bedded massive strutureless } \\
\text { conglomerate }\end{array}$ & $\begin{array}{l}\text { Well bedded conglomerate matrix (very coarse } \\
\text { sand) to clast supported. } \\
\text { Granules to cobbles clasts size. } \\
\text { Unsorted and unclassed. } \\
\text { Erosive surface at base }\end{array}$ & $\begin{array}{l}\text { Planar bed with } 15^{\circ} \text { to } 20^{\circ} \text { dip } \\
1 \text { to } 2 \text { meters thick }\end{array}$ & $\begin{array}{c}\text { Masse freezing } \\
\text { Debris Flow Deposit } \\
\text { 1996) }\end{array}$ & & & & & \\
\hline & G2 & Well bedded fining up conglomerate & $\begin{array}{l}\text { Well bedded matrix supported (coarse sand) } \\
\text { conglomerate. } \\
\text { Clasts size cobbles to granules. } \\
\text { Clasts size fining up and proportion decrease }\end{array}$ & $\begin{array}{l}\text { Planar bed with } 15^{\circ} \text { to } 20^{\circ} \text { dip } \\
1 \text { to } 3 \mathrm{~m} \text { thick }\end{array}$ & $\begin{array}{c}\text { Debris Flow } \\
\text { Gravity processes } \\
\text { (Holmes, 1965; Nemec, 1990 Postma 1990; Miall } \\
\text { 1996) }\end{array}$ & & & & & \\
\hline & G3 & $\begin{array}{l}\text { Cross-bedded pebble to granule } \\
\text { conglomerate } \\
\text { (heterolitic) }\end{array}$ & $\begin{array}{c}\text { Heterolitic conglomerate cross bedded (granules } \\
\text { to cobbles) with a coarse sandy matrix } \\
\text { Large erosion - incision at base with } 15^{\circ} \text { deep } \\
\text { conglomerate deposits }\end{array}$ & $\begin{array}{l}5 \mathrm{~m} \text { thick unit of } 0.2 \text { to } 0.5 \mathrm{~m} \text { thick set } \\
\text { Variable dip from } 0^{\circ} \text { to } 25^{\circ} \\
\text { Poor lateral extension } \\
\text { Antidune - Chute-and-Pool }\end{array}$ & $\begin{array}{l}\text { Multistored Hydraulic Jump } \\
\text { (Cartigny et al., 2014) } \\
\text { (Postma et al., 2014, 1984) }\end{array}$ & & & & & \\
\hline 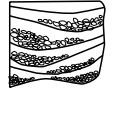 & G4 & $\begin{array}{l}\text { Chute and pools clast supported } \\
\text { pebbles conglomerate }\end{array}$ & $\begin{array}{l}\text { Cobble to pebble clast supported conglomerate } \\
\text { Sometimes lateral grainsize variations and } \\
\text { internal erosion. } \\
\text { Medium sorted and classed } \\
\text { Oblique shear stress at top }\end{array}$ & $\begin{array}{c}0.15 \text { to } 2 \mathrm{~m} \text { thick } \\
\text { Variable dip deposition } \\
\text { High lateral thickness and granulometry variations } \\
\text { Chutes and pools bed geometry }\end{array}$ & $\begin{array}{l}\text { Critical flow conditions } \\
\text { Generated by Hydraulic Jumps } \\
\text { Hyper concentrated flow } \\
\text { (Cartigny et al., 2014) } \\
\text { (Postma et al., 2014, 1984) }\end{array}$ & & & & & \\
\hline 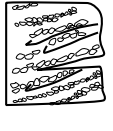 & G5 & $\begin{array}{l}\text { horizontal bedded with internal } \\
\text { backstep cross stratification pebble } \\
\text { conglomerate } \\
\text { (heterolitic) }\end{array}$ & $\begin{array}{c}\text { Cobble to pebble conglomerate } \\
\text { Clast supported } \\
\text { Erosional basal surface } \\
\text { Inverse grading at top } \\
\text { Some pebble layers show an oxidation surface }\end{array}$ & $\begin{array}{l}1 \mathrm{~m} \text { thick bed with } 0.3 \text { to } 0.6 \mathrm{~m} \text { thick set stratification } \\
\text { Horizontal planar bedding } \\
\text { Locally show backstep sets deposit with } \\
\text { chutes and pools features }\end{array}$ & $\begin{array}{l}\text { Downstream to a hydraulic jump } \\
\text { (Cartigny et al., 2014) } \\
\text { (Postma et al., 2014, 1984) }\end{array}$ & & & & & \\
\hline & G6 & $\begin{array}{l}\text { Granules Lenses } \\
\text { (heterolitic) }\end{array}$ & $\begin{array}{l}\text { Granules to locally pebble to conglomerate } \\
\text { Current ripples and by pass features } \\
\text { Normal grading }\end{array}$ & $\begin{array}{l}0 \text { to } 0.3 \mathrm{~m} \text { thick } \\
\text { Large lenses } \\
\text { Undulation features }\end{array}$ & $\begin{array}{l}\text { Critical flow conditions } \\
\text { Generated by hydraulic jump }\end{array}$ & & & & & \\
\hline 6. & GT1 & $\begin{array}{l}\text { Horizontal pebble conglomerate } \\
\text { (heterolitic) }\end{array}$ & $\begin{array}{l}\text { Cobble to pebble conglomerate } \\
\text { Clast supported } \\
\text { Inverse grading at top } \\
\text { Poorly sorted / Graded }\end{array}$ & $\begin{array}{l}20 \mathrm{~cm} \text { to } 1 \mathrm{~m} \text { thick } \\
\text { Horizontal planar bedding }\end{array}$ & $\begin{array}{l}\text { Gravelly High Density } \\
\text { Turbidity (HDT) Deposits } \\
\text { (Facies 8, R3, Lowe 1982) } \\
\text { (Stow \& Johansson, 2000) }\end{array}$ & & & & & \\
\hline 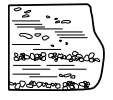 & GT2 & $\begin{array}{l}\text { Horizontal well bedded sandstone } \\
\text { (heterolitic) }\end{array}$ & $\begin{array}{c}\text { Well bedded sandstone fine to coarse with } \\
\text { floating pebbles (isolated to imbricated, traction } \\
\text { carpet) } \\
\text { oxidation traces }\end{array}$ & $\begin{array}{l}1 \mathrm{~cm} \text { to } 1 \mathrm{~m} \text { thick } \\
\text { Horizontal planar bedding }\end{array}$ & $\begin{array}{l}\text { Gravelly High Density } \\
\text { Turbidity Deposits } \\
\text { (Facies 8, S1, Lowe 1982) } \\
\text { (Stow \& Johansson, 2000) }\end{array}$ & & & & & \\
\hline & s1 & $\begin{array}{l}\text { Sandstone with current ripples } \\
\text { (heterolitic) }\end{array}$ & $\begin{array}{l}\text { Fine to coarse sandstone } \\
\text { Planar base } \\
\text { Starved current ripple and by pass features } \\
\text { Vertical Bioturbation }\end{array}$ & $\begin{array}{l}\text { Lenses thickness is } 5 \mathrm{~cm} \\
\text { Undulating geometry }\end{array}$ & $\begin{array}{l}\text { Subcritical flow conditions } \\
\text { By pass }\end{array}$ & & & & & \\
\hline & $\mathrm{F} 1$ & $\begin{array}{l}\text { Horizontal siltstone with aligned } \\
\text { floating pebbles } \\
\text { (heterolitic) }\end{array}$ & $\begin{array}{l}\text { Horizontal planar lamination } \\
\text { Aligned floating clast and or isolated floating } \\
\text { clast (often pebbles) }\end{array}$ & 2 to $10 \mathrm{~cm}$ thick & $\begin{array}{l}\text { Generated by upstream or lateral } \\
\text { Hydraulic Jump }\end{array}$ & & & & & \\
\hline 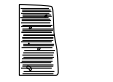 & $\mathrm{F} 2$ & $\begin{array}{l}\text { Horizontal well bedded shales with } \\
\text { rare isolated pebbles } \\
\text { (heterolitic) }\end{array}$ & $\begin{array}{l}\text { Well bedded shales with rare isolated pebble. } \\
\text { Ripples marks and by pass }\end{array}$ & $\begin{array}{l}20 \mathrm{~cm} \text { to } 1 \mathrm{~m} \text { thick of } \\
\text { thin shale layers ( } 1 \text { to } 5 \mathrm{~mm})\end{array}$ & Mainly decantation deposit & & & & & \\
\hline 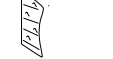 & F3 & Shales & Laminated shales & $\begin{array}{l}\text { Planar bed with } 20^{\circ} \text { dip } \\
1 \text { to } 5 \mathrm{~cm} \text { thick }\end{array}$ & $\begin{array}{l}\text { Latteral decantation } \\
\text { Inactive Foreset }\end{array}$ & & & & & \\
\hline $.00:$ & $\mathrm{x} 1$ & Muddy matrix rich conglomerate & $\begin{array}{l}\text { Clast to matrix supported mud clast } \\
\text { conglomerate. } \\
\text { Erosional Lower and uneven upper boundaries }\end{array}$ & $\begin{array}{l}\text { Thin to medium thick bedded } \\
0.1 \text { to } 0.5 \mathrm{~m} \text { thick }\end{array}$ & $\begin{array}{l}\text { Mudclasts Lag, } \\
\text { Hydraulic fracturing } \\
\text { Local deposition }\end{array}$ & & & & & \\
\hline & $\mathrm{x} 2$ & Chaotic deposit (Slump) & $\begin{array}{c}\text { Chaotic deposits of folded and brecciated blocks } \\
\text { of sediment }\end{array}$ & $\begin{array}{l}\text { Thin to medium thick bedded } \\
0.1 \text { to } 1 \mathrm{~m}\end{array}$ & Slumps and Slides & & & & & \\
\hline
\end{tabular}

The shale deposits without floating clasts (F3) are interpreted as a decantation deposit (Breda et al., 2007) and highlight an inactivity in this foreset area: during a change in the sediment delivery point on the topset or during a lower sediment supply from the delta.

The foreset facies association (For1a) is characterized by gravitydriven flows as debris flow and hyperconcentrated density flow, with episodes of decantation illustrated by mud drapes (For1b), attesting to discontinuous flows or lateral decantations.

\subsubsection{Modified foreset facies association: For2}

Description (i.e. G3, G4, F1; Table 1; Figs. $5 a$ and $6 b$ ): The modified foreset facies association (For2) mainly consists of conglomerates ranging in grain size from cobbles (G3) to granules (G4) and silt lenses (F1). The basal surface of this facies association presents large and deep erosion features and scours. These erosions are filled by ca. 3-5 m-thick units organized in beds with a dip declination ranging from $0^{\circ}$ to $5^{\circ}$ (Figs. 5a and 6b). For2 also exhibits cross-bedded conglomerates with a 


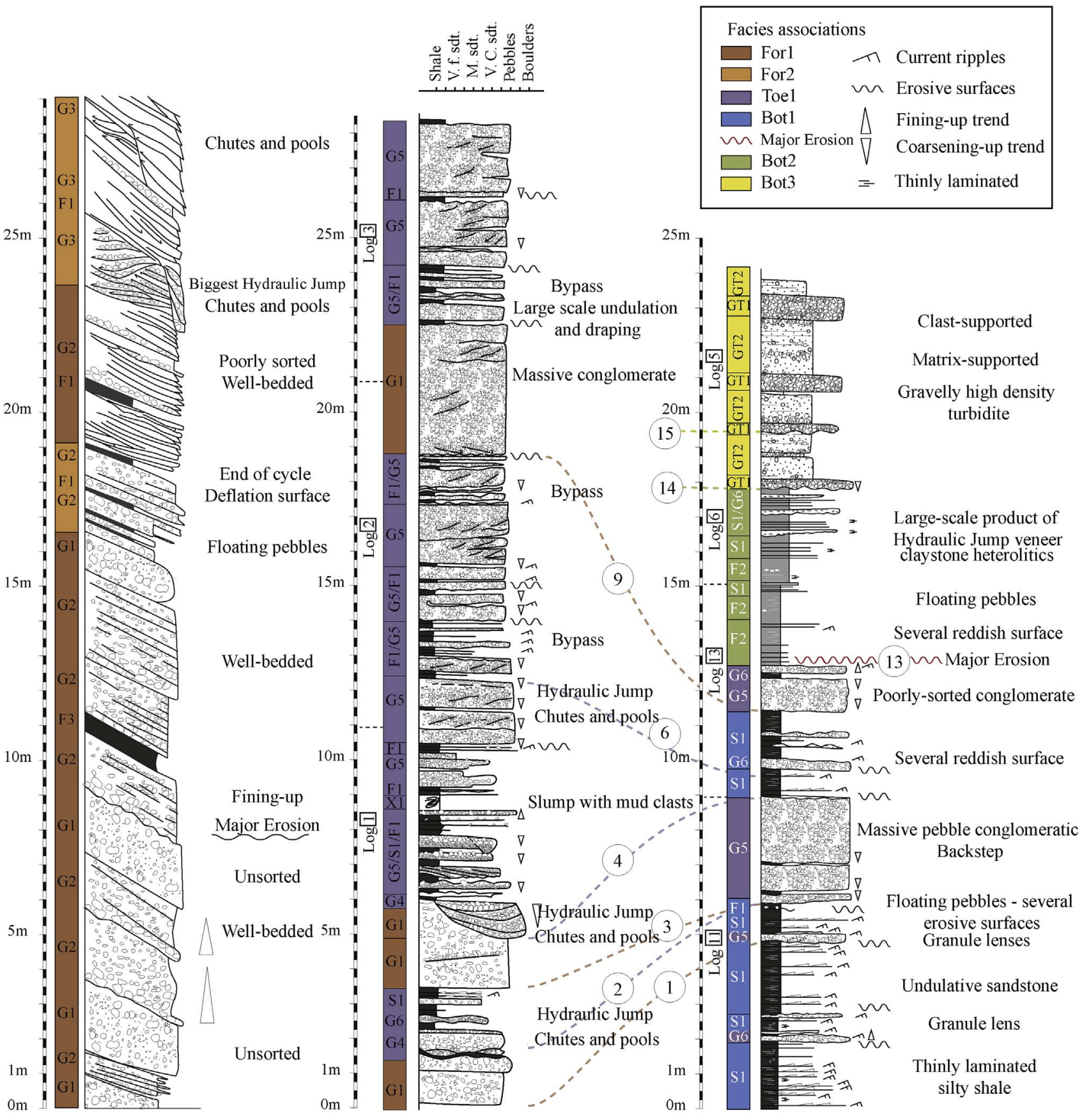

a. Foreset $\log$ type from $\log 16$

b. Toeset log type from $\log 1$ to 3 c. Bottomset log type from log $11,13,6$ and 5

Fig. 5. Sedimentological sections with the facies, facies associations, and key surfaces for the a: foreset; b: toeset; and c: bottomset. See Figs. $2 \mathrm{~d}$ and $4 \mathrm{a}$ for location.

general backstepping bed deposition and antidune, chute-and-pool and cyclic step bedforms. The backstepping bed consists of sub-rounded to rounded clasts showing imbrication structures. The thickness of the conglomerate beds varies from 0.2 to $0.5 \mathrm{~m}$ for G3 facies and from 0.15 to $2 \mathrm{~m}$ for $\mathrm{G} 4$ facies. Conglomerate beds (G3, G4, Table 1) alternate with thin silt lenses (F1) with aligned floating pebbles and current ripples, recording a multiphase deposition event.

Interpretation: The basal erosional surface is interpreted as formed under high velocity currents, i.e. able to erode conglomerate and so promoting deep erosion features and scours. The well-organized fabric of cross-bedded backstepping upslope conglomerates is interpreted as coarse-grained lag deposits (sensu Stevenson et al., 2015) under a high velocity flow building antidune, chute-and-pool and cyclic step bedforms with a dip declination ranging from $0^{\circ}$ to $5^{\circ}$. These bed forms and the upslope migration are key observation to argue for supercritical flow conditions (Smith et al., 2007; Cartigny et al., 2014) and are the witness of hydraulic jump deposits on the delta slope (Massari and Parea, 1990; Massari, 1996; Breda et al., 2007; Fernandez et al., 2011; Clarke et al., 2012; Clarke, 2016). The cross-bedded chute-and-pool conglomerates are so interpreted as coarse-grained lag deposits (sensu Stevenson et al., 2015) under supercritical flow conditions (Cartigny et al., 2014) may generating hydraulic jumps on the slope.

The silt lenses with current ripples are interpreted as a draped erosion surface (sensu Stevenson et al., 2015), with discontinuous lags of coarse-grained sediment, i.e. aligned floating pebbles interbedded with fine-grained facies (Beaubouef et al., 1999). The draped erosion 

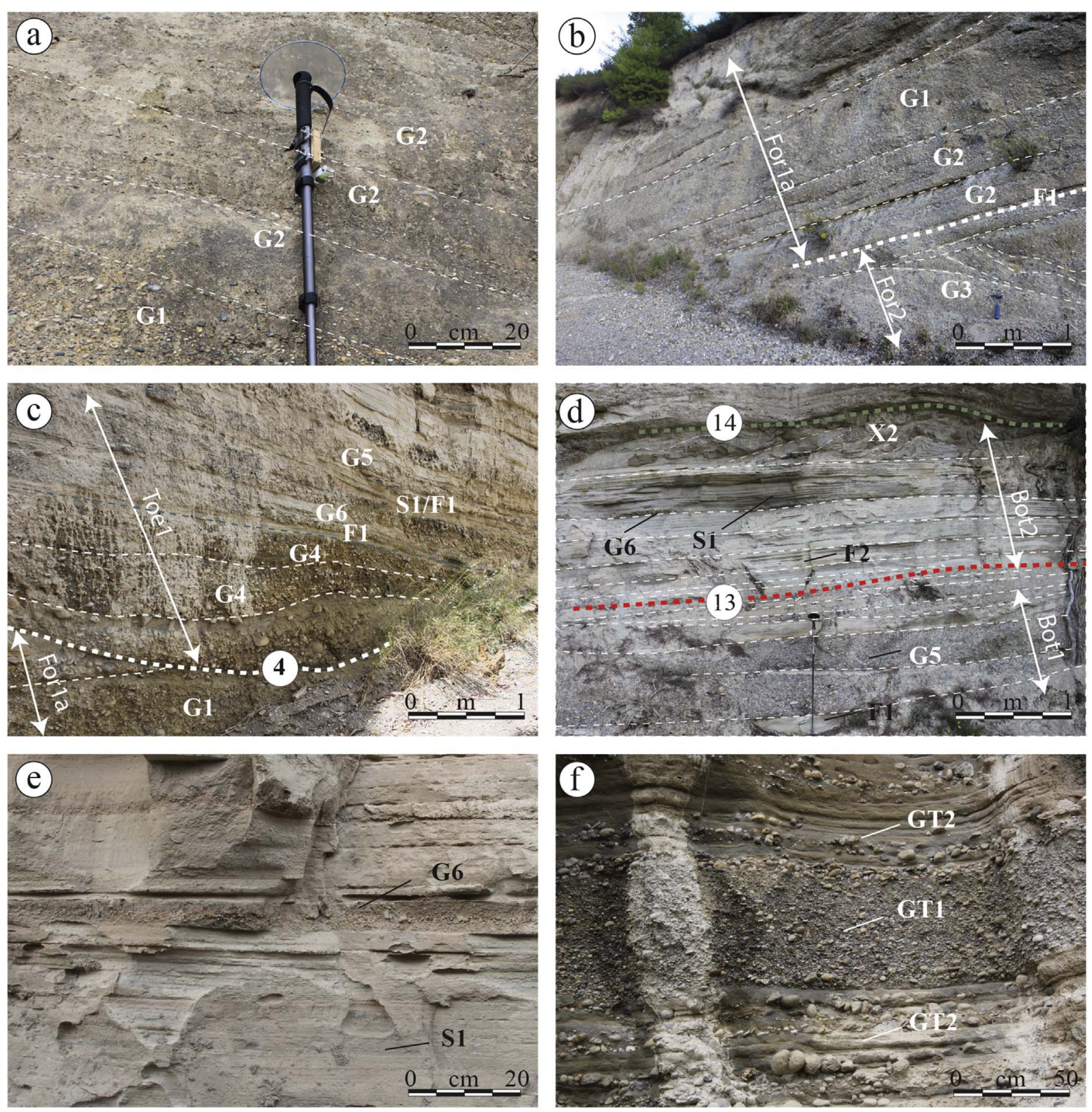

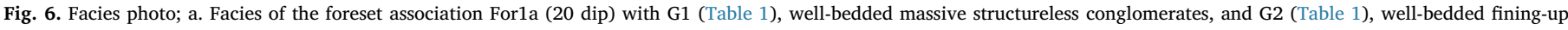

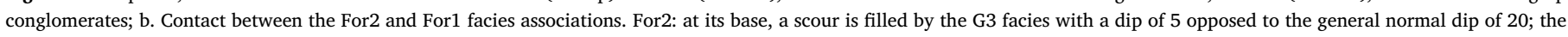

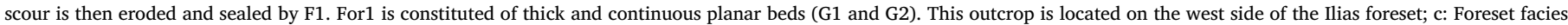

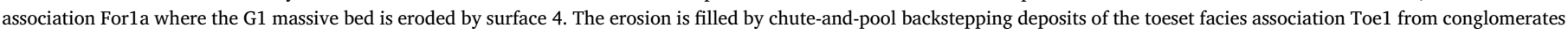

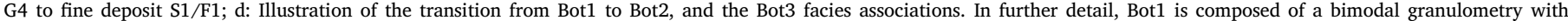

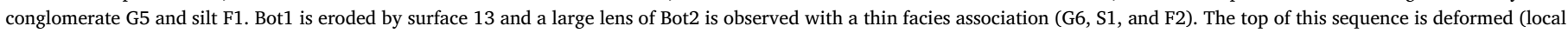

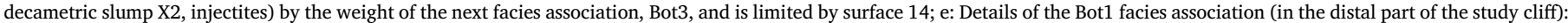

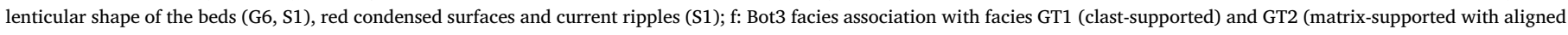
clasts) generated by high-density turbidites. (For interpretation of the references to colour in this figure legend, the reader is referred to the Web version of this article.)

surface is often observed veneering an erosional basal surface of scourand channel-form bodies (Stevenson et al., 2015, and references within). Draped erosional surfaces in the delta foreset are also interpreted as several amalgamation surfaces (sensu Dietrich et al., 2016) onlapping the multi-erosion surfaces.

Consequently, the draped erosion surfaces and coarse-grained lag deposits are key features to identify a major sediment bypass (e.g. Stevenson et al., 2015) during high-energy episodes. High-discharge events such as flooding on the channelized foreset are suitable conditions to generate hydraulic jumps on the delta slope (Breda et al., 2007; Dietrich et al., 2016; Clarke et al., 2012; Clarke, 2016).

\subsubsection{Dip evolution on foreset beds}

When outcrop is not accessible, the slope of the foreset (Fig. 7) was measured with the Virtuoso software. Dip measurements were taken along a vertical cliff measuring $60 \mathrm{~m}$ high. A $10-20 \mathrm{~m}$ escarpment inside the outcrop can be used to take triangulated dip measurements.

During the deposition of the Bot1 facies association, the angle of the foreset beds increases from $19.7^{\circ}$ to $23.6^{\circ}$. It corresponds to the brown lines in Fig. 7 from For1bed $1\left(19.7^{\circ}\right)$ to For1bed $3\left(23.6^{\circ}\right)$. The steepest foreset is reworked to form the For2 facies association. The steepest foreset beds are interpreted as having formed during the maximal progradation of the delta. Then, a major undulating surface erodes the previous foreset beds (ERO on Fig. 7 and corresponding with Line 13 on 


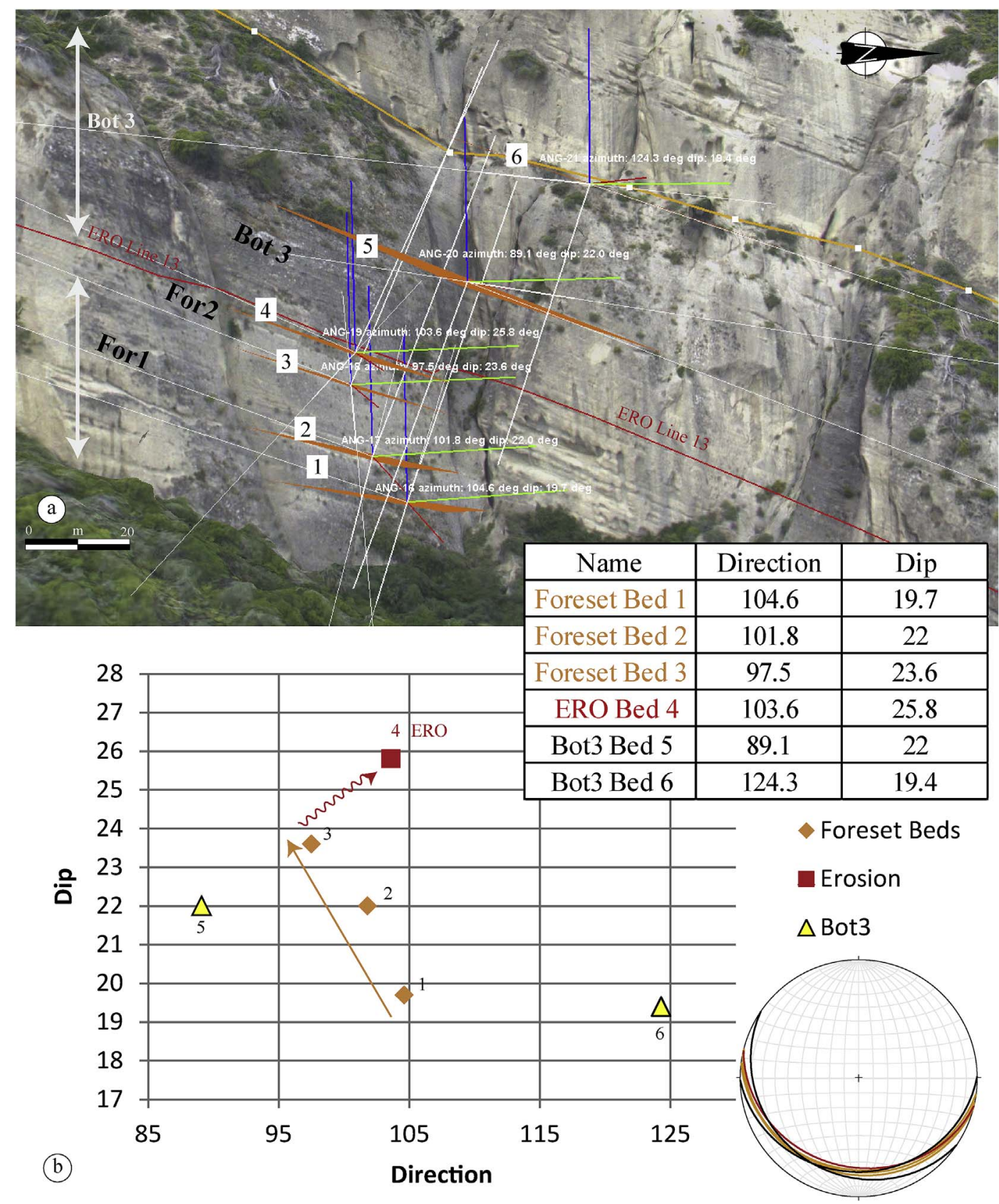

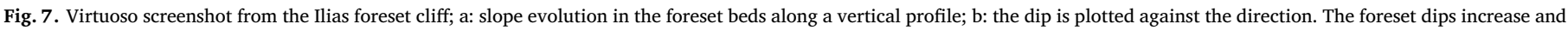
are finally eroded by Ero1 (Line 13). Bot3 onlaps this erosional surface. See Fig. $2 \mathrm{~d}$ for the location.

others figures). This major erosional surface has a dip of $25.8^{\circ}$ which is the maximum measured angle. The same pattern is observed along the outcrop in the underlying deposits, with a foreset slope increase, a foreset beds reworking, and finally foreset beds erosion in their upper part.

\subsection{Toeset}

The toeset outcrop is $15 \mathrm{~m}$ high and $50 \mathrm{~m}$ long with a $15 \mathrm{~m}$ escarpment inside the outcrop, allowing 3D geometries to be determined. The toeset is located at the base of the outcrop and shown with purple lines (Fig. 4b). The toeset comprises the arriving foreset debris flow (For1a) and the toeset facies association (Toe1; Fig. 5b).

\subsubsection{Facies association Toe1}

Description (i.e. G4, G5, G6, S1, F1, X1, X2, Table 1, Figs. 4b, $5 b$ and 6c): The Ilias Gilbert-type Toeset facies association mainly consists of an alternation between silty-sandy deposits (S1, F1) and pebble conglomerates (G4, G5, G6). Both fine- and coarse-grained deposits are organized in lenticular gently dipping beds. Backstepping geometries are common with evidence of antidune, chute-and-pool, and cyclic step bedforms (sensu Cartigny et al., 2014, on Fig. 6c). The cyclic steps have an apparent wavelength about $50 \mathrm{~m}$ in the toeset (see the scale in Fig. 4b) which is a minimal wavelength due to the erosion of the lee side (Clarke, 2016). Cobble to pebble clast-supported conglomerates (G4, G5, G6) are organized in lenticular beds that are $0.15-2 \mathrm{~m}$ thick (Fig. 5b) with a highly variable grain-size distribution. The deposits display lateral bedded subdivisions and significant internal erosions. The top of the beds commonly shows erosion and inverse grading. Siltysandy lenticular deposits present various grain sizes from shales with aligned floating pebbles (F1) to very coarse-grained sandstones (S1) without any bioturbation. Mud clasts lag deposits (X1) and a local 


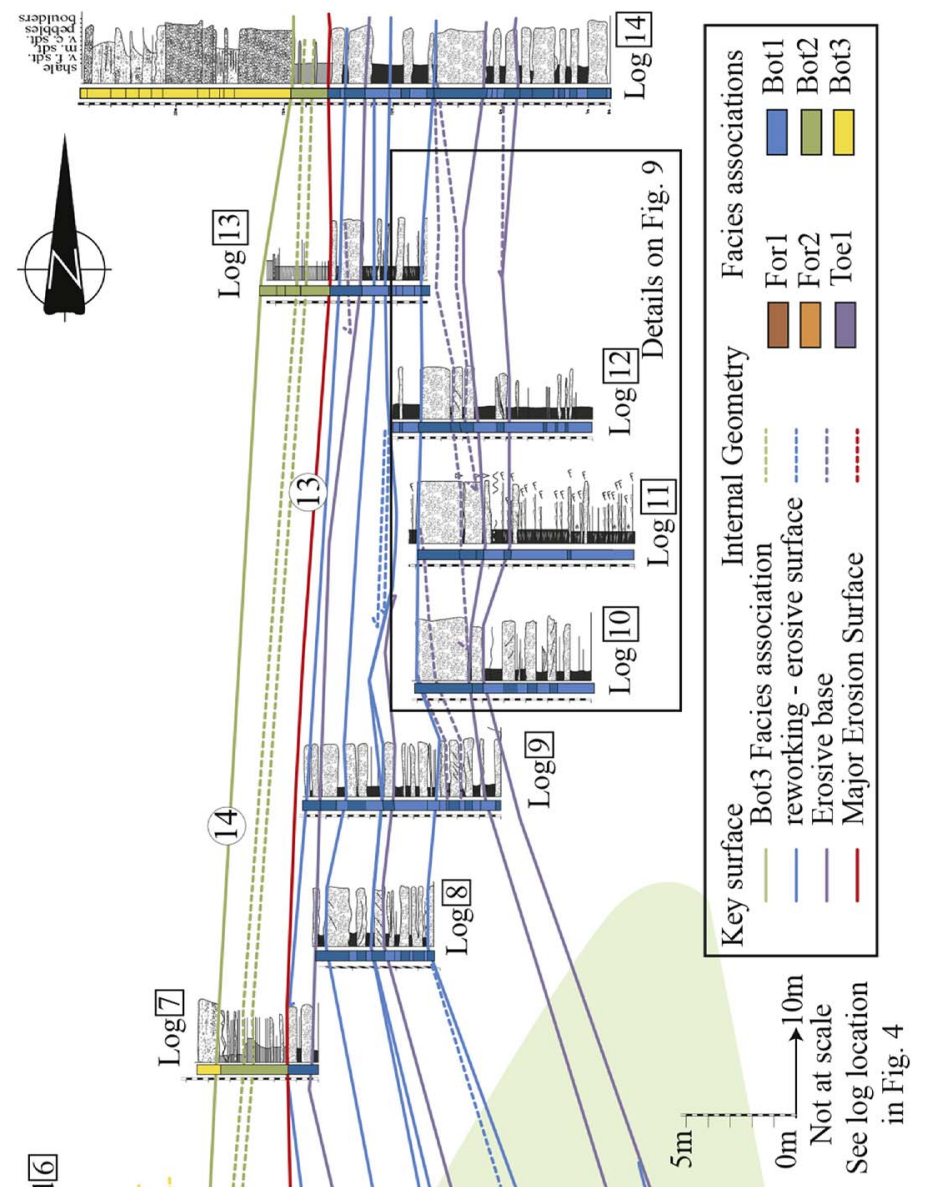

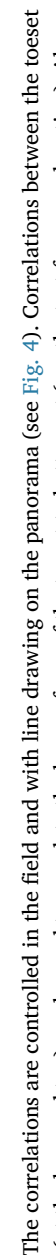
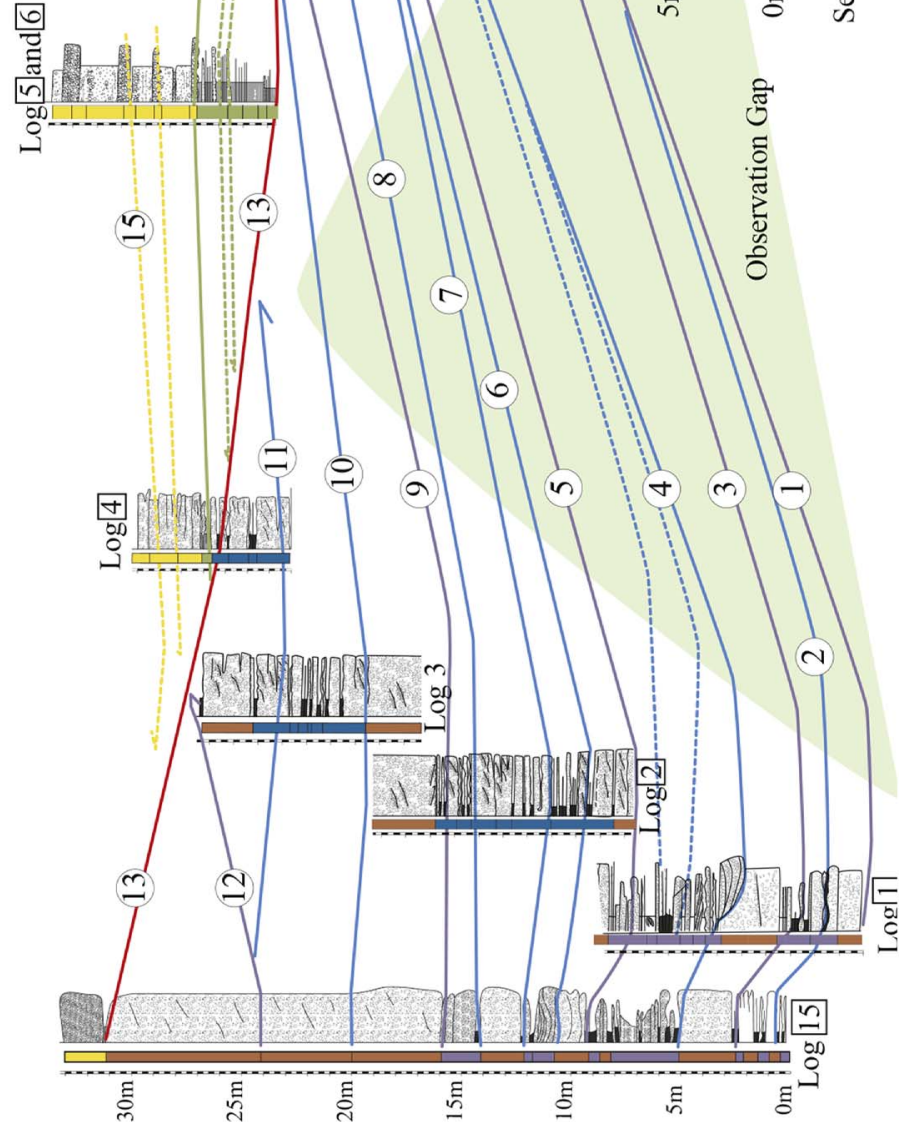

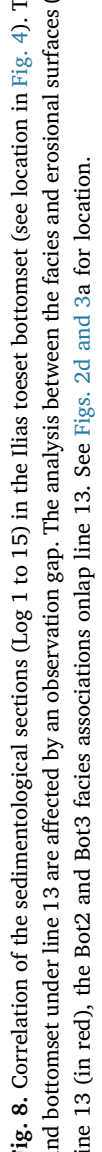


slump (X2), which form 1-20 cm thick beds, are observed only in this facies association.

Vertical evolution in the toeset area: Between lines 1 and 9, the sequences in the toeset area are commonly 5-7 m thick with a fining- and thinning-up trend (Fig. 5b). The toeset sequence is commonly characterized at its base by a $2 \mathrm{~m}$ thick debris flow (For1a) associated with a $\mathrm{dm}$-thick slump (X2) and mud clasts lag deposits (X1). The debris flows are sourced from the foreset, and are deposited above an erosive planar base (purple lines 3, 5, 9, 12 in Figs. 5b and 8). At the top, they are progressively eroded (blue lines 4, 6, 7, 8 in Figs. 5b and 8) and form resedimented chute-and-pool backstepping Toe1 beds (Figs. 4b, 5b and $6 c, 8)$ consisting of lens shaped deposits of very coarse-grained sandstone to fine facies (S1, F1).

Interpretation: The chaotic deposits (X2) associated with muddy matrix-rich conglomerates (X1) are interpreted as products of slumps and slides. The conglomerate and sandstone facies (G4, G5, G6, S1) are interpreted as bypass features recorded by coarse-grained lag deposits (see 4.1.2). The silty-sandy (S1, F1) lenticular deposits are interpreted as draped erosion surface (see 4.1.2). The heterolithic and repetitive character of these deposits are interpreted to be related to periodic flow behaviour.

Additionally, the cyclic steps are interpreted by Cartigny et al. (2014) as a periodic upstream-migrating hydraulic jumps. As the hydraulic jump is located at the slope break, energetic currents erode the delta toe. When the scour becomes too deep, slides occur upstream to stabilize the slope and fill the scour. The top of the debris flows arriving from the foreset (For1a) are progressively eroded and reworked in multi-bedded cyclic-step deposits (Toe1). Moreover, the significant thickness and vertical stacking of the Toe1 facies association, argue for the presence of a stationary hydraulic jump at the bottom of the slope between the delta-slope and basin (Massari and Parea, 1990; Fildani et al., 2006; Kostic and Parker, 2006; Breda et al., 2007). Critical flow develops at the transition between supercritical (Froude number $(\mathrm{Fr})>1$ ) and subcritical flow conditions ( $\mathrm{Fr}<1$ ). A critical flow condition refers to a Fr value equal to 1 . It corresponds to the stage in which the flow experiences the hydraulic jump (Kostic and Parker, 2006), in this case in the toeset area.

\subsection{Bottomset}

Downstream, through the northern part of the Ilias GTD cliff, the beds are generally horizontal to gently northward-dipping (Fig. 4a) and the grain size decreases along the south-north profile. The bottomset package is ca. $40 \mathrm{~m}$ thick with three bottomset facies associations and one major erosion/bypass surface (Fig. 5c). From the base to the top of the cliff, the beds are organized as follows: ca. $15 \mathrm{~m}$ of the Bot1 facies association, one erosive/bypass surface for Ero1, ca. $5 \mathrm{~m}$ of the Bot2 facies association and at least $20 \mathrm{~m}$ of the Bot 3 facies association (Figs. 5c and 8).

\subsubsection{Sandy-gravelly bottomset facies association: Bot1}

The base of the northern cliff is formed by the Bot1 facies association between lines 1 and 9 and is ca. $15 \mathrm{~m}$ thick (Figs. 4 and 8).

Facies description (i.e. G5, G6, S1, F1; Table 1; Figs. 4, 5c, 6d-e): The bottomset facies association (Bot1) consists of a wide range of grain sizes from pebbles to silts forming horizontal to gently dipping beds (Fig. 4c). The top of the beds displays erosional large-scale undulation features. The bottomset facies association is formed by an alternation between two sub-facies associations both presenting lateral thickening and facies variations.

The conglomerates (Bot1a= G5, G6; Table 1; Fig. 5c; base of Fig. 6d) present backset clast imbrication features, internal backset geometries and show basal and upper erosional boundaries. They can also form amalgamated beds with a thickness ranging from $50 \mathrm{~cm}$ to $1.5 \mathrm{~m}$.

Very thinly laminated fine-grained facies $($ Bot $1 \mathrm{~b}=\mathrm{S} 1, \mathrm{~F} 1$, Table 1 ,
Figs. 5c, 6e) also show bypass features such as frequent current ripples, aligned floating clasts, basal and upper erosional boundaries. Rare vertical bioturbations are observed. Bot1b presents important thickness variations from $25 \mathrm{~cm}$ to $3 \mathrm{~m}$.

Architecture description: Details of the Bot1b deposits are presented in Fig. 9 along a single panoramic photograph cut into three parts (a, b and c) with the associated sedimentological logs. Three units are stacked on top of one another in a compensational manner (see the arrows which represent the maximal thickness in Fig. 9).

The first unit (unit A, down line 1, Fig. 9) developed a convex-up geometry forming a lobate geometry, with a maximal thickness of $3 \mathrm{~m}$ on the panorama (part b, Fig. 9). The beds are thicker and coarsergrained away from the apex of the former lobe. Bypass features are characteristic of facies association Bot1b: current ripples, erosional surfaces, lag surfaces and an erosional surface with a 4-5m wavelength. The coarse-grained beds have a lenticular shape and are discontinuous; for example, the G5 bed is $25 \mathrm{~cm}$ thick in part c (at $5 \mathrm{~m}$ on $\log 11$ ) and is totally eroded or non-deposited on parts $a$ and $b$ of the panorama (Fig. 9). Unit A is formed by a positive geometry, with a wavelength of 4-6 $\mathrm{m}$ and a vertical amplitude of $50 \mathrm{~cm}$.

The second unit (unit B, between lines 1 and 2, Fig. 9) is deposited as lateral offset deposit on the previous unit A on the southern part of the outcrop. It is affected by syn-sedimentary normal faulting with a maximal offset of $1 \mathrm{~m}$. In the faulted area, $25 \mathrm{~cm}$ thick coarse-grained beds (G5) alternate with $25 \mathrm{~cm}$ thick finely laminated silt to sand beds with floating pebbles (S1/F1). These beds pinch downstream above the unit A lobe apex and only form erosive surfaces. Unit B fills the low topography created by the lobe geometry of unit A.

The third unit (unit C, between lines 3 and 4, Fig. 9) is a gravelly unit of Bot1a constructed by multiple erosional events. Bot1a beds have a planar basal surface and are eroded with a deep incision $(20 \mathrm{~cm})$. Unit $\mathrm{C}$ is composed of large scale backsets and internal cross-stratification, highlighted by thin silt internal beds. Between logs 9 and 10, separated by $5 \mathrm{~m}$, four $20 \mathrm{~cm}$ thick conglomeratic beds interbedded with $20 \mathrm{~cm}$ thick silt beds ( $\log 9$ ) correlate downstream (log 10) with a massive $2 \mathrm{~m}$ thick conglomeratic bed. The coarse facies (Bot1a) are deposited in lateral compensation and either filled and/or eroded the local low in the topography formed by Bot1b (Fig. 9a). The top of the unit is then eroded by line 4 .

The bottomset beds between lines 4 to 6 are deeply eroded by line 7 (Fig. 8). The erosion is total for Bot1a (above line 5) and it formed an approximately $10 \mathrm{~m}$ long and $1 \mathrm{~m}$ deep depression which is filled by the Bot1b thin beds, onlapping onto the erosional surface 7. Between lines 7 and 8 , thick conglomerate beds ( $\log 8$, Fig. 8) are subdivided downstream into two conglomeratic beds separated by thin silt deposits (log 9). Downstream (roughly $40 \mathrm{~m}$ ), the conglomeratic beds are totally eroded and only erosional surfaces with current ripples are observed ( $\log 13)$. Above line 9, the conglomeratic beds $(\log 7)$ are deeply eroded between logs 9 and 13 and are preserved downstream (logs 13 and 14). Above this conglomerate, the beds are eroded by Ero1 (surface 13).

Cross line description: These observations need to be completed with a perpendicular cross-section to handle the complex 3D architecture: Fig. 10 presents the bottomset architecture, located at a right angle from the other figures, i.e. Figs. 4, 8, 9 (location on Fig. 2d).

The panorama exposed a channel-levee architecture with a channel measuring $15 \mathrm{~m}$ limited by levees with a dip ranging from $25^{\circ}$ to $30^{\circ}$ and a flow direction of $N 55^{\circ} 10^{\circ}$. This section constrains the facies associations: the channel is filled by the Botla facies association and the levees are constructed by Bot1b facies association. At the same stratigraphic level, other channel-levee complexes are observed laterally to this channel, through the south outcropping cliff. The channel-levee complexes are organized in a low-relief morphology with several active channels that are poorly confined by small-sized levees. The channel systems evolve downstream to a large channel belt (30-40 m-wide).

Correlations: The transition between the Toe1 area and bottomset area is poorly exposed in the outcrop (in green, Fig. 8). However, as 

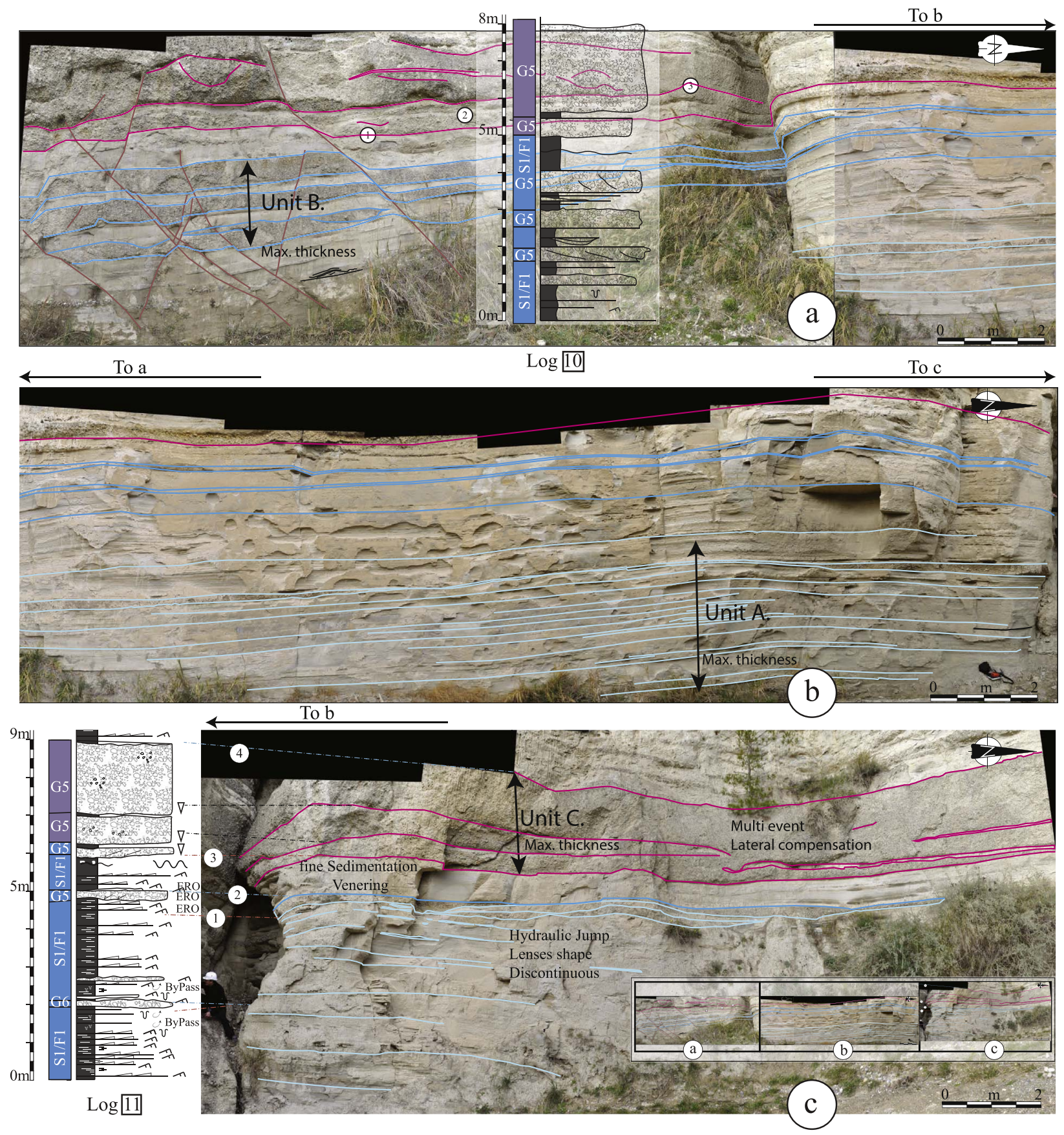

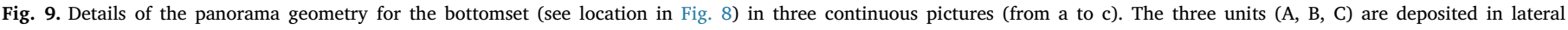

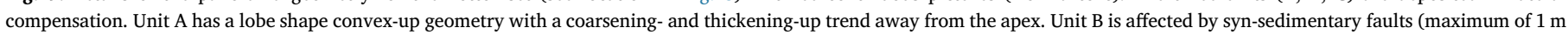

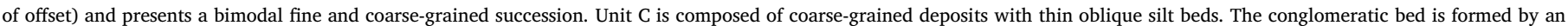
oblique backstepping stratification and is deeply eroded at the top.

shown in Figs. 4 and 8, the erosional surface (line 13) provides a wellconstrained boundary and the dip of the toeset and bottomset beds provides limits for the correlation between the toeset and bottomset. Accordingly, below the major erosional surface (line 13), Toe1 is located upstream (S, Fig. 8) and Bot1 is found downstream (N, Fig. 8).

In order to correlate Toe1 and Bot1, we considered the planar base of the conglomeratic beds (purple lines in Fig. 8) as being relatively continuous. Above the major erosional surface (line 13), Bot2 and Bot3 are not affected by uncertainty (Fig. 4).

Interpretation and sedimentological model: Bot1a with backset clast imbrication features, internal backset geometries and basal and upper erosional boundaries is interpreted as a coarse-grained lag deposits (see
4.1.2) formed through sustained bedload transport process. Bot1b with thin silty beds with current ripples, aligned floating clasts, basal and upper erosional boundaries and rare vertical bioturbations is interpreted as draped erosion surfaces (see 4.1.2) recording by-pass.

Both Bot1a and Bot1b are interbedded in a complex 3D architecture forming low relief channel-levee geometry. Coarse-grained deposits, Bot1a filled the channel and the draped erosion surface, while Bot1b with important thickness variations, built levees that were produced by lateral overflow deposits. The bedload sediments may have partially bypassed the bottomset, and the upper part of the flow mainly bypassed the low relief channel through the basin. The bypassed currents may also contribute to the low relief channel-levee formation. 

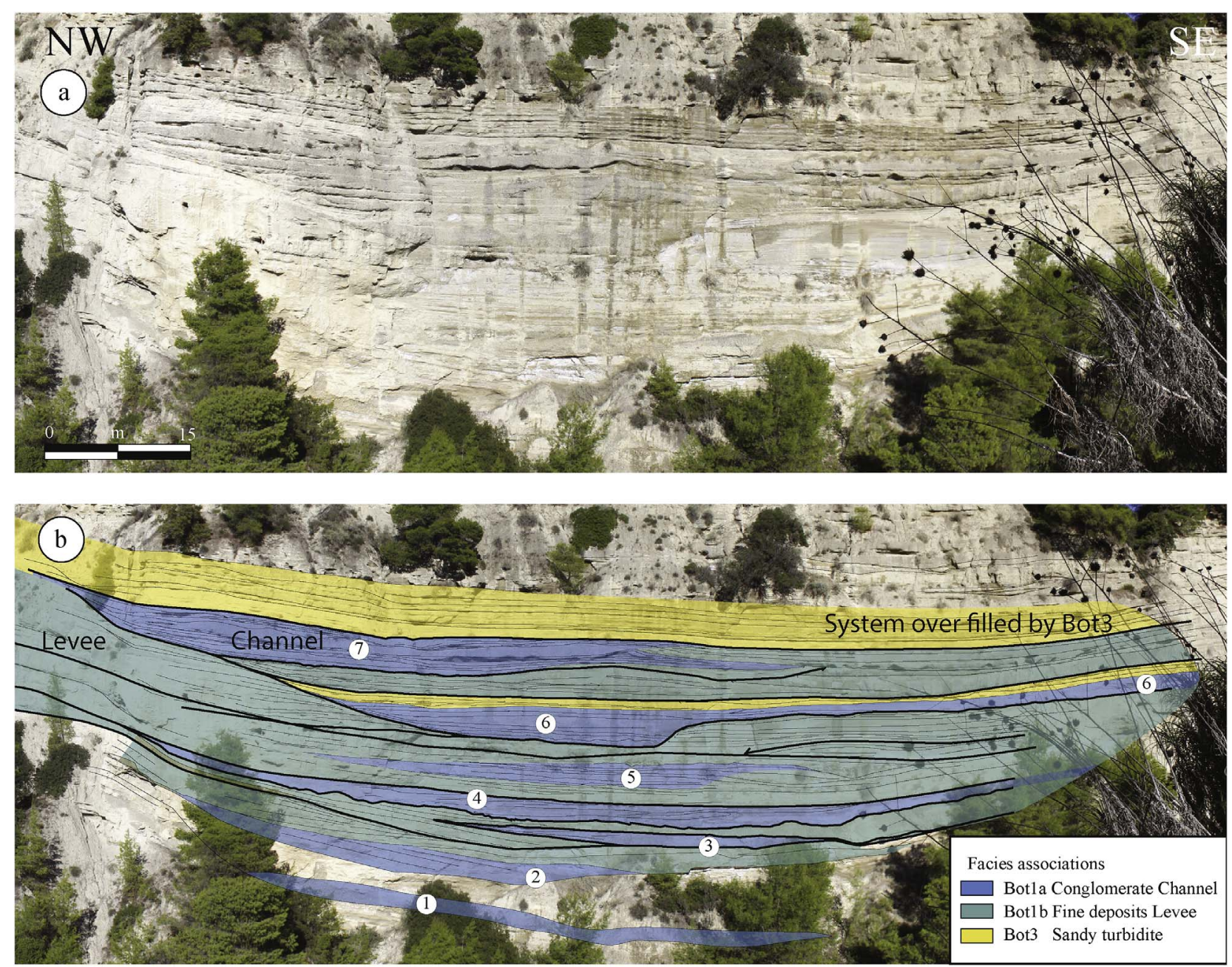

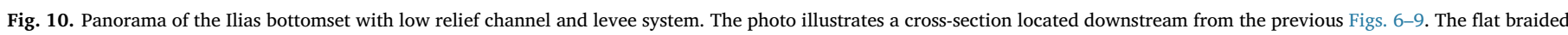

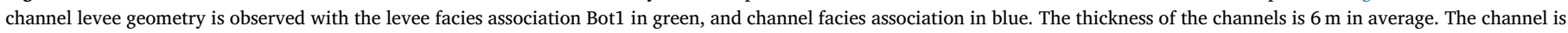

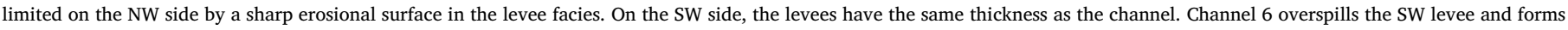

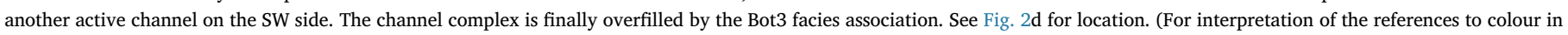
this figure legend, the reader is referred to the Web version of this article.)

Based on the correlations panel (Fig. 8), Bot1 is located downslope of Toe1, i.e. located downstream a hydraulic jump and so deposited under subcritical flow conditions. As highlighted by McCowan (2001), the hydraulic jump produces oblique velocity vectors with an angle of $80^{\circ}$ compared to the axial flow and may produce significant levees. The inception of deep-water channels have been documented from Lucia channel system (California) by initial erosion stages with cyclic steps bedforms bounded by hydraulic jumps (Fildani et al., 2013; Covault et al., 2014). Moreover, the early formation of a channelized geometry immediately downstream from the hydraulic jump was recently proposed by de Leeuw et al. (2016) from lab experiments and they documented that the channel inception is erosional in the upper slope and depositional in the middle and the lower slope.

Coarse-grained sandstone to conglomerate and fine-grained to silt beds have been described as bi-modal sedimentation. By comparing the sedimentological sections, coarse- and fine-grained modified bottomset are respectively associated with Bot1a and Bot1b.

Postma (1984a,b) interpreted the bi-modal sedimentation as the product of a gravity winnowing process, i.e. no erosive currents, limited to the proximal bottomset and the gravel imbrications as shear bands. But the sedimentary by-pass features and cyclic-step bedforms presented above indicate that a hydraulic jump can be inferred to rework and generate constructive bedforms in the bottomset and explain the export of sediment observed in the basin.
Postma and Roep (1985) suggested the presence of a hydraulic jump at the slope break, which transforms slides from the upper delta-slope into a high-density turbulent flow only associated with episodes of coarse-grained sedimentation.

We propose that the hydraulic jump erodes the base of foreset beds, i.e. in toeset, causing a depression and a destabilisation of the lower delta-slope, and that in consequence a debris flow fills the depression. This deposit is then eroded and reworked by the hydraulic jump currents and built downstream the low-relief channel-levee bottomset above erosional surface.

The Bot1 facies association highlights a new typology in the bottomset with low relief channel-levee produced by a stationary hydraulic jump in the toeset. The major part of the sediment is exported to the basin through the channel (Fig. 11a).

\subsubsection{Major erosional surface: Ero1}

The previous deposits (from lines 1 to 12, Figs. 4 and 8) of the toeset and Bot1 facies association are eroded by a major erosion surface: surface 13 (Figs. 4, 5, 6d and 8). This surface is sub-parallel with the bedding in the bottomset, however we observe a deep incision in the conglomeratic bed located just under the erosion surface and a slanting erosion of the toeset beds (Fig. 6d and lines 10, 11, 12 in Fig. 8).

This surface has been already described in the foreset deposits with an erosive angle of $28^{\circ}$ (see section 4.1.3, Fig. 7) and in the toeset area 

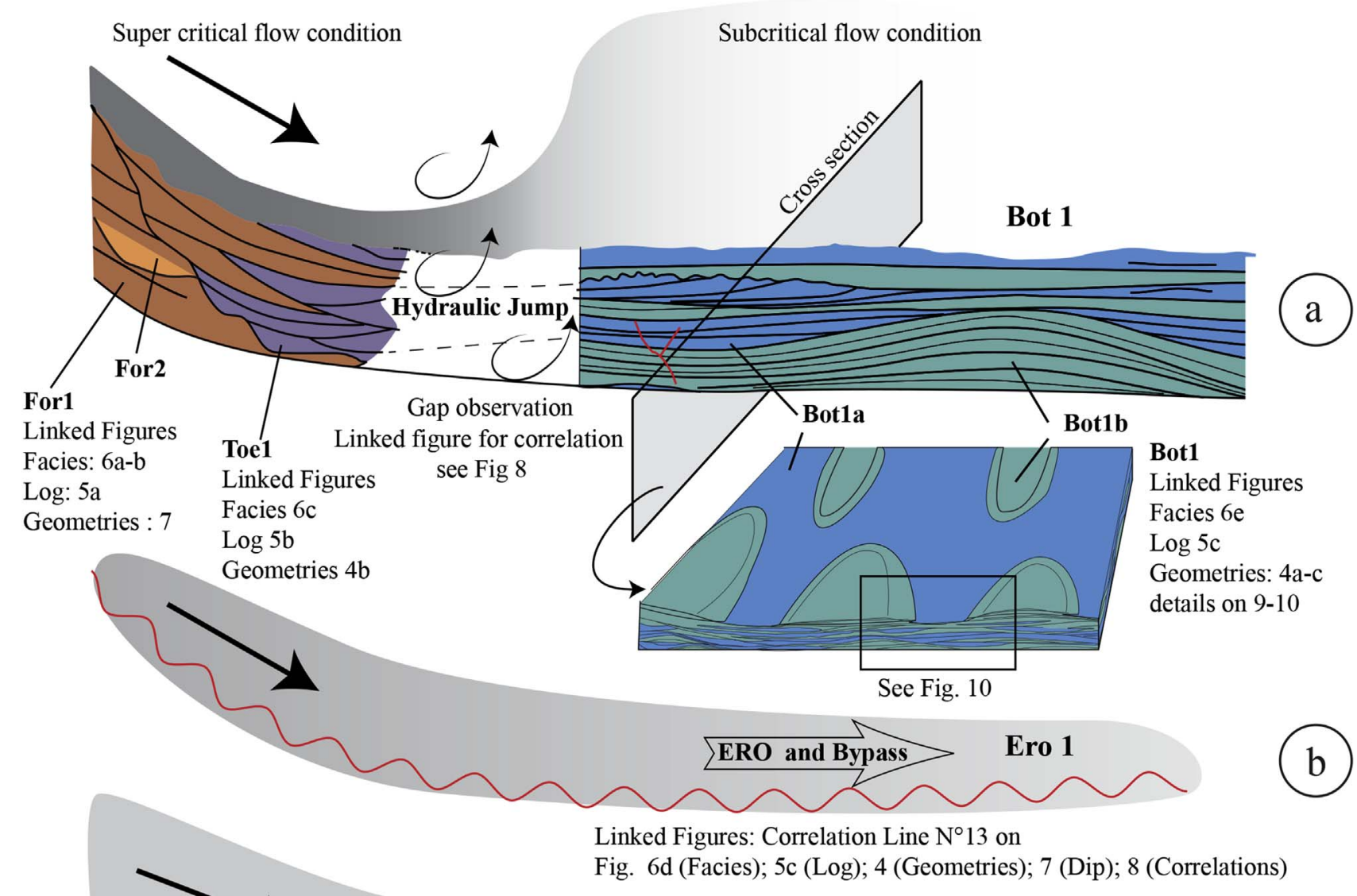

Fig. 6d (Facies); 5c (Log); 4 (Geometries); 7 (Dip); 8 (Correlations)
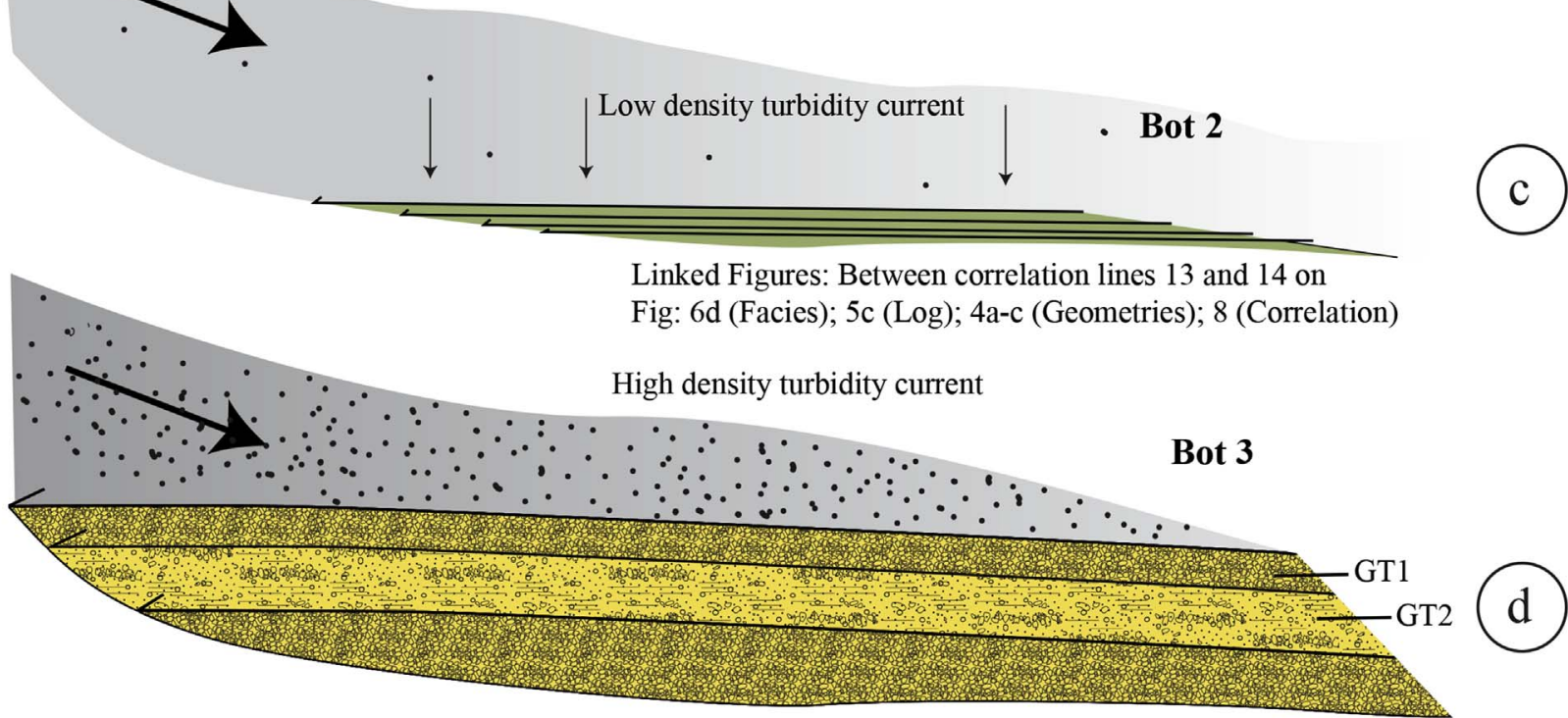

Linked Figures: Up to correlation line 14 on

Fig: 6f (Facies); 5c (Log); 4-7-10 (Geometries); 8 (Correlations)

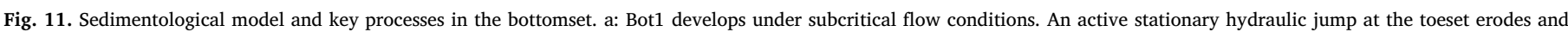

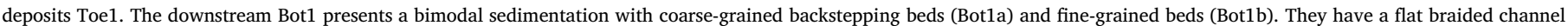

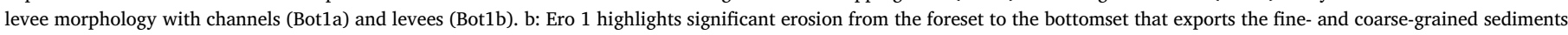

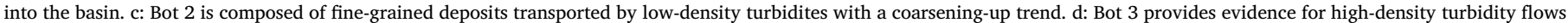
and formed a slope apron on the delta toe.

(see 4.2.1). The overlying bottomset deposits onlap onto this surface (Figs. 4 and 8). Consequently, this surface highlights a major change in the dynamics of the sedimentary system. It corresponds with the stage of maximum progradation of the delta and is marked by the steepest foreset beds. Most of the sediment is exported through the basin and the flow erodes the previous bottomset beds (Fig. 8) and reset the channel- levee relief. This deltaic dynamic is called Ero1; it is illustrated by Fig. 11b and is characterized in the bottomset by a total bypass of the sediment.

This stage without bottomset deposit can be compared with the trapezoidal fan delta (Poulimenos et al., 1993); the lack of bottomsets can be explained by a total sediment bypass and or erosion in the 


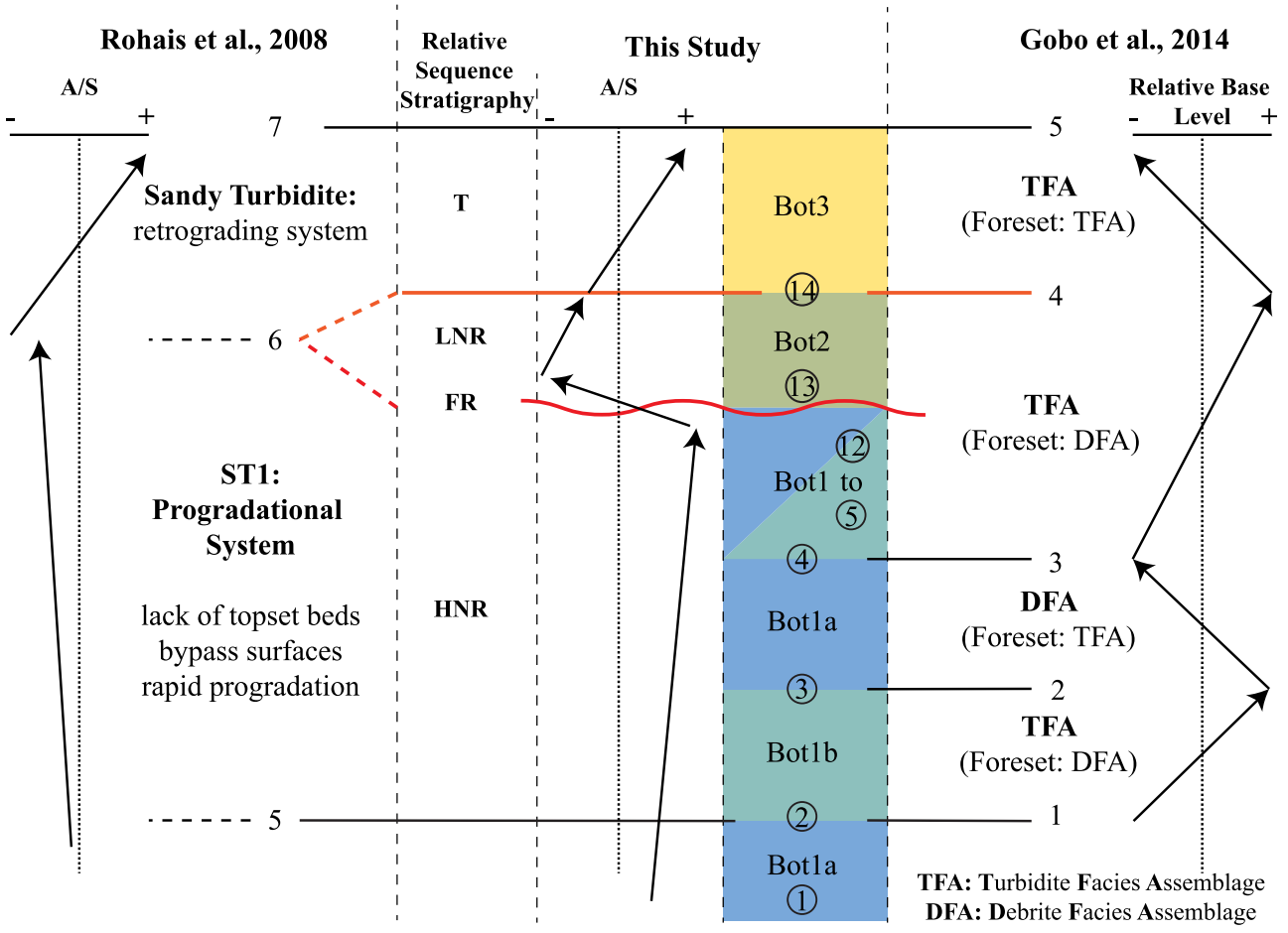

Fig. 12. Comparison of the line correlations and stratigraphic cycles, i.e. relative base level cycles, between Rohais et al. (2008), Gobo et al. (2014) and this study. Assuming a constant sediment supply (S), we only consider the variation of the accommodation (A), which is related to the Relative Water Level (RWL). The RWL trend is in line with Rohais et al. (2008) proposition but we detail the Progradational System (ST1) by identifying Bot1, Ero1, Bot2 generated during HNR, FR, and LNR stages, respectively. The processes used by Gobo et al. (2014) model explain the incoherency between the models. Rohais et al (2008) and our study agree with a transgressive stage during the deposition of Bot3, contrary to Gobo et al. (2014) who propose that the TFA prevails during the RWL fall. bottomset area (Doutsos and Poulimenos, 1992).

\subsubsection{Fine-grained bottomset facies association: Bot2}

The Bot2 facies association is ca. $5 \mathrm{~m}$ thick above line 13 (Fig. $5 \mathrm{c}$ ). Description (i.e. G6, S1, F1, F2, X1, X2; Table 1; Figs. 4, 5c, 6d and 8): The fine-grained facies association (Bot2) is organized in large lenses ( $80 \mathrm{~m}$ long and $5 \mathrm{~m}$ thick, Fig. 4c between surfaces 13 and 14). Bot2 onlaps the foreset beds and overlies the previous unit of the bottomset (Bot1). It fills the toeset area and presents a general coarsening-up trend.

The lenses are constituted of a large-scale veneering of heterolitic claystone to siltstone that is thinly laminated with rare isolated floating pebbles. At the base of the lens, several reddish surfaces with current ripples are observed. At the top, the finest facies F2 and F1 are eroded by sandy S1 and gravely lenses G6 (Fig. 6d). Facies G6 and F1 show bypass features as undulating beds and current ripples. Several metric slumps (X2) and mudclasts (X1) are observed at the top of the lens.

Interpretation and sedimentological model: The thin $(5 \mathrm{~m})$ lenses with a coarsening-up trend are interpreted as the result of decantation (F2) and low concentrated turbidite (F1). Then, occurrence of current ripples and few undulating beds argue for turbulent flows (Stevenson et al., 2015) possibly under subcritical flows. The metric slumps are interpreted as the result of an overloading that destabilized the Bot2 facies association. This bottomset stage is interpreted as a starved bottomset. Moreover, the coarse-grained sediments being absent, they are assumed to be stored upstream, in the drainage basin or in the delta topset. The sedimentological model is shown in Fig. 11c.

In the Gilbert model, the bottomset is preliminary the result of hypopycnal processes: the finest sediments are carried far out in suspension by the superficial stream and selectively sinks to the bottom depending on the grain size. The fine-grained bottomset facies association Bot2, deposited from low density turbidity currents and that onlap on the foreset beds can be associated with the Gilbert model. The transition between the foreset and bottomset can be formed by two architectures: downlap of the foreset beds or onlap of the bottomset beds depending on the $\mathrm{A} / \mathrm{S}$ ratio.

\subsubsection{Massive sandy bottomset facies association: Bot3}

The Bot 3 facies association is at least $20 \mathrm{~m}$ thick above Bot2, line 14 (Fig. 5c).

Description (i.e. GT1, GT2; Table 1; Figs. 4, 5c, 6 f and 8): The massive sandy to gravely bottomset facies association consists of planar horizontal to gently dipping bed geometries with an erosive base. This facies association is formed by very poorly sorted, pebble to granule conglomerates containing either clast-supported (GT1) or matrix-supported coarse-to medium-grained sand (GT2), with occasionally aligned and imbricated pebbles (Fig. 6f). These deposits are organized in $0.30-1 \mathrm{~m}$ thick beds showing a fining- and thinning-upward trend. Locally, the beds present inverse grading at the top. The first massive sandy deposit presents a general large-scale cross backstep sets (Fig. 4a).

The general architecture of the beds onlaps onto the underlying foreset and forms a coarse-grained slope-apron system. The internal slope of Bot3 (Figs. 4, 7a and 8) decreases sharply and the bedding becomes horizontal $17 \mathrm{~m}$ above the erosional surface. The previous channels and levee deposits are overfilled by Bot3 (yellow lines in Fig. 10b).

Interpretation and sedimentological model: The massive poorly sorted, clast-to matrix-supported (GT1 - GT2), sandy to gravely deposits in the bottomset and metric bedding are interpreted as being generated by two processes: sandy debris flow (SDF) and high-density turbidity (HDT) currents (sensu Stow and Johansson, 2000) respectively correspond with hyperconcentrated to concentrated density flow (sensu Mulder and Alexander, 2001). The very thick sand beds devoid of primary sedimentary structures are characteristic of the Deep Water Massive Sands (DWMS, Stow and Johansson, 2000). The coarse clastsize, granule to pebble, and the lobate architecture of the beds are characteristic of type I of DWMS, located in proximal systems dominated by coarse-grained facies. We can interpret Bot3 as type I DWMS deposits (sensu Stow and Johansson, 2000), developing preferentially along the tectonically active margin, downstream from the braided delta system, and forming a coarse-grained slope-apron system, which covers the system. Thus, to the best of the authors knowledge, the first evidence of DWMS in the bottomset area of a GTD is documented. Bot3 covers the system by forming an overlap of sandy-rich lobe, so the 
conglomerates are mainly stored upstream, i.e. in the topset or in the catchment area. Due to the lack of foreset beds and the onlap of Bot3 on the slope of the delta (Fig. 4), the flow carrying the sand must by pass the foreset area and collapses/deposes in the bottomset to form a sandy slope apron. The lack of fine-grained deposits is interpreted as being exported through the basin by turbidity currents (Fig. 11d). We suggest that the flow may experience hydraulic jumps in the upper part of the delta, i.e. in the topset and/or upper foreset, that deposed most of the conglomerates and spreading the sand through the bottomset area.

\section{Discussion}

\subsection{Comparison with results from previous studies}

A comparison between previous studies (Rohais et al., 2008; Gobo et al., 2014) and the present study summarizes the line drawings on the Ilias GTD (Fig. 12). In order to compare the studies, we refer to the ratio between accommodation (A) and sediment supply (S). The progradational trend (with $\mathrm{A} / \mathrm{S}<1$, i.e. stratigraphic base level fall) is linked with the record of either a relative water level (RWL) drop or an increase in sediment supply while the retrograding system $(\mathrm{A} / \mathrm{S}>1$, i.e. stratigraphic base level rise) is linked either with a RWL increase or with a decrease in sediment supply.

Between our lines 1 to 14, the stratigraphic model established by Rohais et al. (2008) proposed an interpretation in one trend: ST1 is a progradational trend, corresponding to the Bot1 facies association presented in our study. ST1 is characterized by the lack of topset beds, which have been eroded, the presence of bypass surfaces and the rapid progradation of the GTD (Rohais et al., 2008). The Bot2 facies association has no equivalence and is merged in between the erosional lines 13 and 14 (this study) in the surface 6 presented by Rohais et al. (2008). By comparing the sedimentological sections of Gobo et al. (2014), our section and the line correlations (Fig. 12), the facies association debrite dominated assemblage (DFA) and turbidite dominated assemblage (TFA) respectively correspond to Bot1a and Bot1b facies associations (described in 4.3.1) under the line 13. We do not interpret DFA as a debris-flow deposit in the bottomset as proposed by Gobo et al. (2014) because we document low relief channel beds generated by upstream stationary hydraulic jump in the toeset. Gobo et al. (2014) proposed a DFA in the bottomset during the drop in the relative water level and a TFA during the rise in the relative water level with a coeval reciprocity in the foresets. They correlated their observations with an autocyclic process between the foreset and bottomset and an allocyclic process for the dominant facies assemblage in the delta. Gobo et al. (2014) interpreted the TFA and DFA deposits as due to short-term variations in the relative water level. Nevertheless, the photogrammetric data (Fig. 7) and correlation panel resulting from our study (Fig. 8) do not support the correlation lines proposed by Gobo et al. (2014). For example, the TFA has not been observed in the foresets underlying the line 13 (Fig. 8). So, the coeval reciprocity between foreset-bottomset beds could be challenged.

Above our line 14, we agree with previously published descriptions for Bot3, with on one hand the massive sandy turbidite of Rohais et al. (2008), and on the other the TFA with no coeval reciprocity in the foreset of Gobo et al. (2014) (Fig. 12). However, the interpretations proposed by these authors were completely opposite: 1) Rohais et al. (2008) interpreted these beds as a retrograding trend with a landward shift in the position of the offlap break; and 2) Gobo et al. (2014), proposed that the TFA prevailed during base level fall. We do not agree with the deposition of the TFA during base level fall (Gobo et al., 2014) because it is contradictory with the aggrading, onlapping and backstepping trends of these deposits. Moreover, the facies and related processes encompassed in the Bot 3 facies association also indicate that the incoming flow was already turbulent in the upper part of the former foreset, suggesting that the former topset was flooded.

\subsection{Autocyclic behaviour}

The clinoform morphologies and growth pattern under conditions of high sediment supply and/or lateral confinement and over steep basin slopes had been modelled by Gerber et al. (2008) with numerical models, flume approaches and outcrop comparison. These authors fixed constant parameters such as the flow discharge (which is already turbulent), grain size and water level and obtained an autogenic cycle growth pattern. Gerber et al. (2008) documented a unique style of progradation driven by autogenic cycles of slope steepening. Then, the sediments bypassed the slope and deposited a sediment lobe basinward. Continued deposition caused the lobe to backstep up the slope building a lower-slope foreset and eventually reinitiating the cycle.

This model is in line with the outcrop observations: 1) the increase in the angle of the foreset beds just prior to the deposition of Bot3 facies association, 2) the major erosional surface 3) the lack of foreset deposits during the Bot3 stage, 4) the lobe-slope apron geometry of Bot3, and 5) the retrograding trend of the Bot3 deposit.

Moreover, this model is also coherent with the alternative explanation for the genesis of the DWMS by the High Density Turbidites (HDT) put forth by Stow and Johansson (2000). Indeed, DWMS were interpreted to be deposited by continuous aggradation/collapse/fall-out from a HDT that experiences a hydraulic jump.

The Bot3 deposits could therefore be interpreted as resulting from an autocyclic clinoform process produced by turbulent flow. It implies that the entire former topset was sufficiently flooded to experience turbulent flow, or at least flow characterized by hydraulic jump dynamic (Fig. 11). Dalla Valle et al. (2013) developed a similar model and interpreted the DWMS clinoform deposit as the mouth of slope-confined gullies which corresponds with their type 1 slope-confined gullies. However, this model does not explain the presence of the Bot1 and Bot2 facies associations and the relationship between these three types of bottomset deposits as illustrated in Fig. 11.

\subsection{Stratigraphic model}

The stratigraphic architecture is the result of the interplay between accommodation, i.e. relative sea or lake level and tectonic vertical offset, and sediment supply. In this study, we consider the A/S ratio variations as the dominant factor controlling the stratigraphic architecture and we can refer to the terminology given by Catuneanu et al. (2009) for the sequence stratigraphy. We could thus propose a relationship between the four stages of bottomset dynamic identified in this study and the stratigraphic architecture of the related Gilbert-type delta.

\subsubsection{Bot 1: sandy-gravelly bottomset stratigraphic stage}

Bot1 typology of bottomset is characterized by a low relief channellevee architecture generated by a stationary hydraulic jump in the toeset area (Toe1) linked with active foreset, i.e. For1a or For2 facies association (Fig. 11a). This building stage for both the delta foreset and bottomset could be related to an increase in sediment supply and/or a diminution of the accommodation. The preservation of the toeset and bottomset area needs an aggradation trend which is supported by the aggrado-progradation of the corresponding foreset beds (Fig. 13a). Then, the progradation rate increase with time and the aggradation rate decrease with time. This deltaic dynamic could correspond to the highstand normal regression, sensu Catuneanu et al. (2009).

\subsubsection{Ero 1: major erosional stratigraphic stage}

The foreset beds are affected by deep scouring and these depressions are filled by cyclic step beds. Both the erosions and the deposits are generated by the hydraulic jumps migrating upslope (For2 facies association). The foreset slope increased and a major erosional surface (line 13) highlights the end of the cycle (Figs. 7, 8 and Fig. 7). This delta architecture with steep foreset and major erosion/bypass are 
a: Highstand Normal Regression (A/S $>1$ - Bot1)

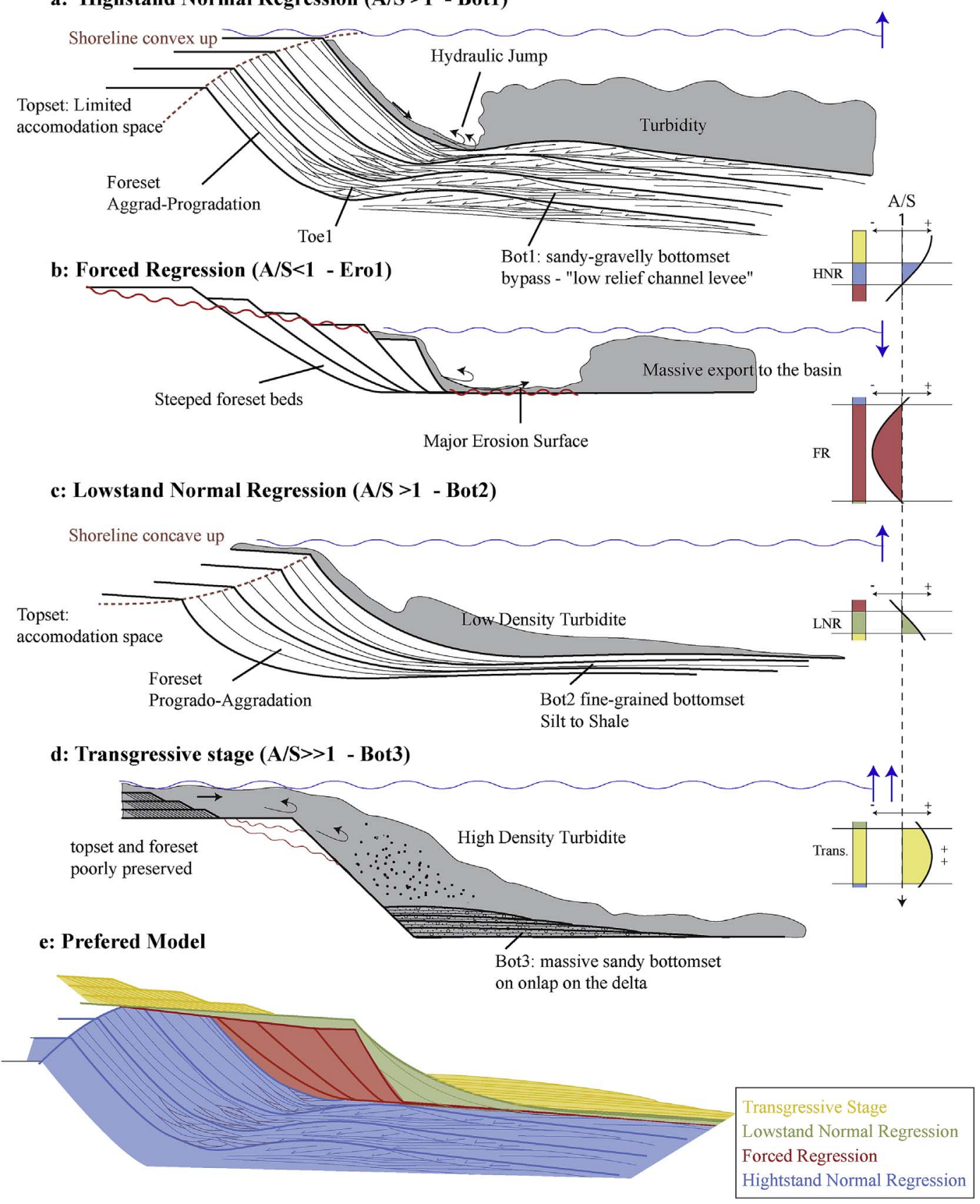

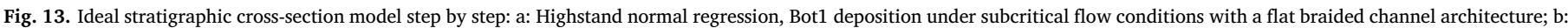

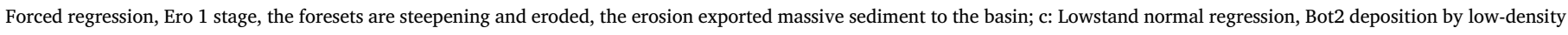

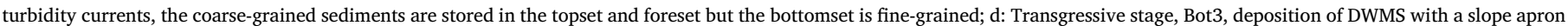
geometry; e: Completed stratigraphic model showing the final architecture of the delta.

interpreted as the maximum of progradation in the delta evolution (Fig. 13b). This delta dynamic is interpreted as an important decrease in accommodation and a major increase in sediment supply. Moreover, such evidence of a hydraulic jump upstream from the slope break has been highlighted by modelling studies (Kostic and Parker, 2006), experimental (Garcia and Parker, 1989; Cartigny et al., 2014), field works (Russell and Arnott, 2003; Postma et al., 2014; Dietrich et al., 2016) and in situ delta monitoring (Clarke et al., 2012; Clarke, 2016). This suggests that the sediments were exported to the foreset by a longlasting (Dalla Valle et al., 2013) and very thick critical density flow probably related to hyperpycnal conditions (Mulder and Syvitski, 1995; Piper and Normark, 2009) or related to river discharge flowing near the bottom without water density control (Clarke, 2016). It could be related to a major bypass and/or erosion dynamic in the delta topset. This phase could correspond to the forced regression, sensu Catuneanu et al. (2009).

\subsubsection{Bot 2: fine-grained bottomset stratigraphic stage}

The bottomset only records shale to silt-size sediments respectively deposited by decantation or low energetic turbidity currents. Bot2 facies association overlies the previous erosional surface and present a lenticular geometry. Thin-bedded and fine-grained deposits are interpreted as witnesses of a sharp decrease of sediment supply and/or an increase of accommodation. The active deltaic system is consequently located upstream so the major part of the sediment is stored in the topset and foreset (Fig. 13c). The aggradation rate increases with time 
and the progradation rate decreases with time (Catuneanu et al., 2009). This delta dynamic can be interpreted as the lowstand normal regression, sensu Catuneanu et al. (2009).

\subsubsection{Bot3: massive sandy bottomset stratigraphic stage}

The overall architecture of the bot 3 typology presents onlaps on the foreset beds, i.e. a retrograding trend as proposed by Rohais et al. (2008). The onlaps and the retrograding trend imply a A/S > 1, and therefore a decrease in sediment supply and/or an increase in accommodation. But the massive sandy bottomset with coarse-grained sediments and thick beds document a high rate of sediment supply. In consequence, Bot3 dynamic results of a high sediment supply linked with a higher accommodation rate $(\mathrm{A} / \mathrm{S}>>1)$. This delta dynamic can be interpreted as the transgressive stage with high sediment supply, sensu Catuneanu et al. (2009).

Conventional sequence-stratigraphic concepts assume that the delivery of sand to the deep water domain occurs primarily during the relative sea level fall and lowstand deposits (Posamentier and Vail, 1988; Johannessen and Steel, 2005; Helland-Hansen and Hampson, 2009; Gobo et al., 2014). The basinward transport is associated with a shelf-edge incision and sediment bypass (Van Wagonier et al., 1988; Johannessen and Steel, 2005). Nevertheless, significant sand volumes can also be transported to the deep water domain during the relative sea level rise and highstand deposits (rewied by Dalla Valle et al., 2013). This has already been postulated by Burgess and Hovius (1998) and documented by other authors (Meckel and Galloway, 1996; Dixon et al., 2012; Carvajal and Steel, 2006). Coarse-grained outer-shelf sand ridges developed during highstand periods with formation of clinoforms have been observed in the Pescara Basin and Central Adriatic Basin (Dalla Valle et al., 2013), in the Gulf of Lion (Berne et al., 1998; Bassetti et al., 2006), Gulf of Cadiz (Lobo et al., 2005), Ebro continental margin (Lo Iacono et al., 2010) and northern Adriatic Sea (Storms et al., 2008).

\section{Conclusions and perspectives}

The Ilias Gilbert-type bottomsets record four key successive stages of evolution with distinctive sedimentary processes and related depositional profiles (Fig. 13e). Each typology has specific characteristics: facies, facies association, internal architecture, geometry and depositional processes. Sandy-gravelly bottomset (Bot1), erosional-bypass bottomset (Ero1), fine-grained bottomset (Bot2) and massive sandy bottomset (Bot3) typologies have been integrated for the first time within a stratigraphic framework.

This study provides key elements to recognize the specific facies and architectures of the different bottomset typologies. The sedimentary model enhances the process formation knowledge, with a focus on the hydraulic jump behaviour. To establish the sequence stratigraphy, autocyclic processes and the resulting architecture have been identified to recognize the allocyclic parameters. The allocyclic parameters have been handled by the ratio between accommodation (A) and sediment supply (S). This approach allows to propose an original sequence stratigraphy model for Gilbert-type delta bottomset and a guideline for quantifying the amount of sediments exported basinward.

The gravelly bottomset Bot1, is interpreted to occur primarily during the highstand normal regression of the Gilbert-type delta. The flow erodes the steep foreset with deep scours and fills them with reworked sediments; they then form cyclic steps and anti-dune deposits. These features are characteristic of a critical-flow that experiences a hydraulic jump. The principal flow creates a confined channel and develops an active foreset probably due to hyperpycnal conditions. Laterally, decantation processes control the shale deposition in the inactive part of the foreset.

When arriving in the toeset, the flow experiences a stationary hydraulic jump, deposits thick cyclic step beds at the slope break, and the subcritical flow bypasses and reworks the bottomset. In the toeset, retrogressive erosion due to the hydraulic jump may have induced a slump and slide from the proximal foreset beds. The bottomset is formed of the Bot1 facies association with a flat and low relief braided channel-levee geometry and a backstepping chute-and-pool bedform. The bottomset is characterized by starved current ripples, erosion surfaces, veneering, floating clasts, bi-modal grain-size distribution and general backset geometries.

Secondly, the forced regression stage is marked by steeper foresets than during the previous stage and by erosional surfaces instead of bottomset deposits. The upstream topset and foreset are then eroded and the sediments are mainly exported to the basin. In the bottomset, this stage is recorded with a major erosional surface (Ero1). Additional studies on the related turbiditic system should be carried out to support and update the timing for maximum sediment delivery into the deep basin.

Thirdly, during the lowstand normal regression, a starved bottomset (Bot2) is deposited onto the erosional surface. This bottomset contains very fine-grained sediments, the coarse-grained deposits being primarily stored upstream in the delta topset and foreset.

Fourthly, the Bot3 develops during the transgressive to highstand stage of the Gilbert-type delta evolution. On the flooded former topset, the incoming flow is already turbulent and then erodes the foreset. Bot3 is very poorly sorted, sub-horizontal and onlaps onto the foreset beds. Bot3 beds form a slope apron in the delta foot. The major part of the coarse-grained sediments is stored in the bottomset area and is interpreted as having been generated by high-density turbidity currents.

These sedimentary and stratigraphic models improve the prediction for the sand distribution and the connectivity between the various parts of the delta in clastic depositional systems with a high-sediment discharge and a high accommodation rate.

\section{Acknowledgements}

This research is funded by Engie and managed by the CNRS and Engie. We thank Remi Dreux, Bertrand Coureaud and Julien Schmitz for the drone acquisition and modelling processing. We would like to thank the Exploration and Production Engie team and Céline Ducassou for their help and constructive remarks. Anonymous reviewers and Dr. David J.W. Piper greatly improved the quality of the manuscript.

\section{References}

Bassetti, M.A., Jouet, G., Dufois, F., Berné, S., Rabineau, M., Taviani, M., 2006. Sand bodies at the shelf edge in the Gulf of Lions (Western Mediterranean): deglacial history and modern processes. Mar. Geol. 234 (1-4), 93-109.

Beaubouef, R., Rossen, C., Zelt, F., Sullivan, M., Mohrig, D., Jennette, D., 1999. Deepwater sandstones, Brushy canyon formation, West Texas. In: Continuing Education Course Notes. American Association of Petroleum Geologists, pp. 1-50.

Berne, S., Lericolais, G., Marsset, T., Bourillet, J.F., De Batist, M., 1998. Erosional offshore sand ridges and lowstand shorefaces; examples from tide- and wave-dominated environments of France. J. Sediment. Res. 68 (4), 540-555.

Billiris, H., Paradissis, D., Veis, G., England, P., Featherstone, W., Parsons, B., Cross, P., Rands, P., Rayson, M., Sellers, P., Ashkenazi, V., Davison, M., Jackson, J., Ambraseys, N., mar 1991. Geodetic determination of tectonic deformation in central Greece from 1900 to 1988. Nature 350 (6314), 124-129. http://www.nature.com/doifinder/10. 1038/350124a0.

Bornhold, D., Prior, D., 1988. Submarine morphology and processes of fjord fan deltas and related high-gradient systems: modern examples from British Columbia. In: Nemec, W., Steel, R. (Eds.), Fan Deltas: Sedimentology and Tectonic Settings. Blackie, London, pp. 125-143.

Breda, A., Mellere, D., Massari, F., aug 2007. Facies and processes in a gilbert-delta-filled incised valley (Pliocene of Ventimiglia, NW Italy). Sediment. Geol. 200 (1-2), 31-55. http://www.sciencedirect.com/science/article/pii/S0037073807000796.

Briole, P., Rigo, A., Lyon-Caen, H., Ruegg, J.C., Papazissi, K., Mitsakaki, C., Balodimou, A., Veis, G., Hatzfeld, D., Deschamps, A., 2000. Active deformation of the Corinth Rift, Greece: results from repeated global positioning system surveys between 1990 and 1995. J. Geophys. Res. 105 (B11), 25605. http://doi.wiley.com/10.1029/ 2000JB900148.

Burgess, P.M., Hovius, N., 1998. Rates of delta progradation during highstands: consequences for timing of deposition in deep-marine systems. J. Geol. Soc. 155 (2), 217-222.

Cartigny, M.J.B., Ventra, D., Postma, G., van Den Berg, J.H., 2014. Morphodynamics and sedimentary structures of bedforms under supercritical-flow conditions: new insights 
from flume experiments. Sedimentology 61 (3), 712-748. http://dx.doi.org/10. $1111 /$ sed.12076.

Carvajal, C.R., Steel, R.J., 2006. Thick turbidite successions from supply-dominated shelves during sea-level highstand. Geology 34 (8), 665-668.

Catuneanu, O., Abreu, V., Bhattacharya, J.P., Blum, M.D., Dalrymple, R.W., Eriksson, P.G., Fielding, C.R., Fisher, W.L., Galloway, W.E., Gibling, M.R., Giles, K.A., Holbrook, J.M., Jordan, R., Kendall, C.G.S.C., Macurda, B., Martinsen, O.J., Miall, A.D., Neal, J.E., Nummedal, D., Pomar, L., Posamentier, H.W., Pratt, B.R., Sarg, J.F., Shanley, K.W., Steel, R.J., Strasser, A., Tucker, M.E., Winker, C., 2009. Towards the standardization of sequence stratigraphy. Earth Sci. Rev. 92 (1-2), 1-33. https://doi. org $/ 10.1016 /$ j.earscirev.2008.10.003.

Clarke, J.E.H., 2016. First wide-angle view of channelized turbidity currents links migrating cyclic steps to flow characteristics. Nat. Commun. 7, 11896.

Clarke, J.E.H., Brucker, S., Muggah, J., Hamilton, T., Cartwright, D., Church, I., Kuus, P., 2012. Temporal progression and spatial extent of mass wasting events on the Squamish prodelta slope. Landslides and engineered slopes: protecting society through improved understanding. 122, 1091-1096.

Clarke, P.J., Davies, R.R., England, P.C., Parsons, B.E., Billiris, H., Paradissis, D., Veis, G., Denys, P.H., Cross, P.A., Ashkenazi, V., Bingley, R., jun 1997. Geodetic estimate of seismic hazard in the Gulf of Korinthos. Geophys. Res. Lett. 24 (11), 1303-1306 doi.wiley.com/10.1029/97GL01042.

Clément, C., Sachpazi, M., Charvis, P., Graindorge, D., Laigle, M., Hirn, A., Zafiropoulos, G., oct 2004. Reflectionrefraction seismics in the Gulf of Corinth: hints at deep structure and control of the deep marine basin. Tectonophysics 391 (1-4), 97-108. http://linkinghub.elsevier.com/retrieve/pii/S0040195104002264.

Colella, A., De Boer, P., Nio, S., 1987. Sedimentology of a marine intermontane pleistocene gilbert-type fan-delta complex in the crati basin, calabria, southern Italy. Sedimentology 34 (4), 721-736.

Covault, J.A., Kostic, S., Paull, C.K., Ryan, H.F., Fildani, A., 2014. Submarine channel initiation, filling and maintenance from sea-floor geomorphology and morphodynamic modelling of cyclic steps. Sedimentology 61 (4), 1031-1054.

Dalla Valle, G., Gamberi, F., Trincardi, F., Baglioni, L., Errera, A., Rocchini, P., 2013. Contrasting slope channel styles on a prograding mud-prone margin. Mar. Petrol. Geol. 41 (1), 72-82. https://doi.org/10.1016/j.marpetgeo.2012.02.003.

Dart, C.J., Hill, E., Oex, S.T.W., Collier, R.E.L.I., Gawthorpe, R.L., Keller, J.V.A., Nichols, G., 1994. Sequence stratigraphy of (?) Pliocene- Quaternary synrift, Gilbert-type fan deltas ,Greece. Mar. Petrol. Geol. 11 (5), 545-560.

de Leeuw, J., Eggenhuisen, J.T., Cartigny, M.J.B., 2016. Morphodynamics of submarine channel inception revealed by new experimental approach. Nat. Commun. 7, 10886. http://www.nature.com/doifinder/10.1038/ncomms10886.

Dietrich, P., Ghienne, J.-F., Normandeau, A., Lajeunesse, P., feb 2016. Upslope-migrating bedforms in a Proglacial Sandur delta: cyclic steps from river-derived underflows? J. Sediment. Res. 86 (2), 113-123. http://jsedres.sepmonline.org/lookup/doi/10. 2110/jsr.2016.4.

Dixon, J.F., Steel, R.J., Olariu, C., 2012. Shelf-edge delta regime as a predictor of deepwater deposition. J. Sediment. Res. 82 (9), 681-687.

Dorsey, R.J., Umhoefer, P.J., Renne, P.R., aug 1995. Rapid subsidence and stacked gilbert-type fan deltas, Pliocene Loreto basin, Baja California Sur, Mexico. Sediment. Geol. 98 (1-4), 181-204. http://linkinghub.elsevier.com/retrieve/pii/ 0037073895000324.

Doutsos, T., Poulimenos, G., jun 1992. Geometry and kinematics of active faults and their seismotectonic significance in the western Corinth-Patras rift (Greece). J. Struct. Geol. 14 (6), 689-699. http://linkinghub.elsevier.com/retrieve/pii/ $019181419290126 \mathrm{H}$.

Ferentinos, G., Papatheodorou, G., Collins, M., sep 1988. Sediment Transport processes on an active submarine fault escarpment: gulf of Corinth, Greece. Mar. Geol. 83 (1-4), 43-61. http://linkinghub.elsevier.com/retrieve/pii/0025322788900515.

Fernandez, R.L., Cauchon-Voyer, G., Locat, J., Dai, H.-H., Garcia, M.H., Parker, G., 2011 Co-evolving delta faces under the condition of a moving sediment source. J. Hydraul. Res. 49 (1), $42-54$.

Fildani, A., Hubbard, S.M., Covault, J.A., Maier, K.L., Romans, B.W., Traer, M., Rowland, J.C., 2013. Erosion at inception of deep-sea channels. Mar. Petrol. Geol. 41, 48-61. https://doi.org/10.1016/j.marpetgeo.2012.03.006.

Fildani, A., Normark, W.R., Kostic, S., Parker, G., 2006. Channel formation by flow stripping: large-scale scour features along the Monterey East Channel and their relation to sediment waves. Sedimentology 53 (6), 1265-1287.

Garcia, M., Parker, G., 1989. Experiments on hydraulic jumps in turbidity currents near a canyon-fan transition. Science (New York, N.Y.) 245 (4916), 393-396.

Gawthorpe, R.L., Colella, A., jan 1990. Tectonic controls on coarse-grained delta depositional systems in rift basins. Special Publ. Int. Assoc. Sedimentol. 10, 113-127.

Gerber, T.P., Pratson, L.F., Wolinsky, M. a., Steel, R., Mohr, J., Swenson, J.B., Paola, C. 2008. Clinoform progradation by turbidity currents: modeling and experiments. J. Sediment. Res. 78 (3), 220-238.

Gilbert, G.K., 1885. The Topographic Features of Lake Shores. US Government Printing Office.

Gobo, K., Ghinassi, M., Nemec, W., 2014. Reciprocal changes in foreset to bottomset facies in a gilbert-type delta: response to short-term changes in base level. J. Sediment. Res. 84 (11), 1079-1095.

Helland-Hansen, W., Hampson, G.J., 2009. Trajectory analysis: concepts and applications. Basin Res. 21 (5), 454-483.

Horton, B.K., Schmitt, J.G., feb 1996. Sedimentology of a lacustrine fan-delta system, Miocene Horse Camp formation, Nevada, USA. Sedimentology 43 (1), 133-155. http://doi.wiley.com/10.1111/j.1365-3091.1996.tb01464.x.

Johannessen, E.P., Steel, R.J., 2005. Shelf-margin clinoforms and prediction of deepwater sands. Basin Res. 17 (4), 521-550.

Jolivet, L., Brun, J.-P., Gautier, P., Lallemant, S., Patriat, M., 1994. 3D-kinematics of extension in the Aegean region from the early Miocene to the present, insights from the ductile crust. Bulletin - Societe Geologique de France 165 (3), 195-209.

Kostaschuk, R.A., McCann, S.B., 1989. Submarine slope stability of a fjord delta; Bella Coola, british columbia. Géogr. Phys. Quaternaire 43 (1), 87-95.

Kostic, S., Parker, G., 2006. The response of turbidity currents to a canyonfan transition: internal hydraulic jumps and depositional signatures. J. Hydraul. Res. 44 (5), 631-653.

Lo Iacono, C., Guillén, J., Puig, P., Ribó, M., Ballesteros, M., Palanques, A., Lí Farrán, M., Acosta, J., oct 2010. Large-scale bedforms along a tideless outer shelf setting in the western Mediterranean. Continent. Shelf Res. 30 (17), 1802-1813. http://linkinghub. elsevier.com/retrieve/pii/S0278434310002621.

Lobo, F., Fernández-Salas, L., Hernández-Molina, F., González, R., Dias, J., del Río, V.D., Somoza, L., aug 2005. Holocene highstand deposits in the Gulf of Cadiz, SW Iberian Peninsula: a high-resolution record of hierarchical environmental changes. Mar. Geol. 219 (2-3), 109-131. http://linkinghub.elsevier.com/retrieve/pii/ S0025322705001830.

Lowe, D.R., 1982. Sediment gravity flows: II depositional models with special reference to the deposits of high-density turbidity currents. SEPM Journal of Sedimentary Research 52 (1), 279-297.

Massari, F., 1996. Upper-flow-regime stratification types on steep-face, coarse-grained, gilbert-type progradational wedges (Pleistocene, Southern Italy). SEPM Journal of Sedimentary Research 66.

Massari, F., Colella, A., 1988. Evolution and types of fan delta systems in some major tectonic setting. In: Nemec, W., Steel, R. (Eds.), Fan Deltas Sedimentology and Tectonic Settings, sixth ed. Blackie, London, pp. 103-122.

Massari, F., Parea, G.C., 1990. Wave-dominated gilbert-type gravel deltas in the Hinterland of the gulf of Taranto (pleistocene, southern Italy). In: Coarse-grained Deltas. Blackwell Publishing Ltd, Oxford, UK, pp. 311-331. http://doi.wiley.com/10. 1002/9781444303858.ch18.

McCowan, A., 2001. Improving the performance of a two-dimensional hydraulic model for floodplain applications. In: 6th Conference on Hydraulics in Civil Engineering: the State of Hydraulics. Institution of Engineers, Australia, pp. 55. Proceedings. No. November. http://search.informit.com.au/documentSummary; $\mathrm{dn}=$ 521741235414023;res = IELENG.

Meckel, L., Galloway, W., 1996. Formation of high-frequency sequences and their bounding surfaces: case study of the Eocene Yegua Formation, Texas Gulf Coast, USA. Sediment. Geol. 102 (1-2), 155-186.

Moretti, I., Sakellariou, D., Lykousis, V., Micarelli, L., aug 2003. The Gulf of Corinth: an active half graben? J. Geodyn. 36 (1-2), 323-340. http://linkinghub.elsevier.com/ retrieve/pii/S026437070300053X

Mulder, T., Alexander, J., 2001. The physical character of subaqueous sedimentary density flow and their deposits. Sedimentology 48 (2), 269-299.

Mulder, T., Syvitski, J.P., 1995. Turbidity currents generated at river mouths during exceptional discharges to the world oceans. J. Geol. 103 (3), 285-299.

Nemec, W., 1990. Aspects of sediment movement on steep delta slopes. In: Coarse-grained Deltas. Blackwell Publishing Ltd, Oxford, UK, pp. 29-73. http://doi.wiley.com/10. 1002/9781444303858.ch3.

Nixon, C.W., McNeill, L.C., Bull, J.M., Bell, R.E., Gawthorpe, R.L., Henstock, T.J. Christodoulou, D., Ford, M., Taylor, B., Sakellariou, D., Ferentinos, G., Papatheodorou, G., Leeder, M.R., Collier, R.E., Goodliffe, A.M., Sachpazi, M., Kranis, H., may 2016. Rapid spatiotemporal variations in rift structure during development of the Corinth Rift, central Greece. Tectonics 35 (5), 1225-1248. http://doi.wiley. com/10.1002/2015TC004026.

Papanikolaou, D., Gouliotis, L., Triantaphyllou, M., jan 2009. The IteaAmfissa detachment: a pre-Corinth rift Miocene extensional structure in central Greece. Geological Society, London, Special Publications 311 (1), 293-310. http://sp.lyellcollection.org/ content/311/1/293.abstract.

Piper, D.J.W., Normark, W.R., 2009. Processes that initiate turbidity currents and their influence on turbidites: a marine geology Perspective. J. Sediment. Res. 79, 347-362.

Posamentier, H.W., Vail, P.R., 1988. Eustatic controls on clastic deposition II - sequence and systems tract models. In: Sea-level Changes. SEPM (Society for Sedimentary Geology), pp. 125-154.

Postma, G., 1984a. Mass-flow conglomerates in a submarine canyon: Abrioja fan-delta, Pliocene, Southeast Spain. Sedimentology of Gravels and Conglomerates Memoir 10, 237-256.

Postma, G., 1984b. Slumps and their deposits in fan delta front and slope ( sedimentation model, Spain). Geology 12, 27-30.

Postma, G., Kleverlaan, K., Cartigny, M.J.B., 2014. Recognition of Cyclic Steps in Sandy and Gravelly Turbidite Sequences, and Consequences for the Bouma Facies Model.

Postma, G., Roep, T.B., 1985. Resedimented conglomerates in the bottomsets of gilberttype gravel deltas. SEPM Journal of Sedimentary Research 55 (6), 874-885.

Poulimenos, G., Zelilidis, A., Kontopoulos, N., Doutsos, T., sep 1993. Geometry of trapezoidal fan deltas and their relationship to extensional faulting along the southwestern active margins of the Corinth rift, Greece. Basin Res. 5 (3), 179-192. http:// doi.wiley.com/10.1111/j.1365-2117.1993.tb00064.x.

Prior, 1981. Submarine chutes on the slopes of fjord deltas. Nature 290, 326-328.

Prior, D., Bornhold, B., 1988. Submarine morphology and processes of fjord fan deltas and related high-gradient systems: modern examples from british columbia. Fan deltas: sedimentology and tectonic settings 125-143.

Rohais, S., Eschard, R., Ford, M., Guillocheau, F., Moretti, I., 2007. Stratigraphic architecture of the Plio-pleistocene infill of the Corinth rift : implications for its structural evolution. Tectonophysics 440, 5-28.

Rohais, S., Eschard, R., Guillocheau, F., 2008. Depositional model and stratigraphic architecture of rift climax Gilbert-type fan deltas ( Gulf of Corinth, Greece ). Sediment. Geol. 210, 132-145.

Rohais, S., Moretti, I., 2017. Structural and stratigraphic architecture of the Corinth rift 
(Greece): an intergrated onshore to offshore basin-scale synthesis. In: Roure, F., Amin, A., Khomsi, S., Al-Garni, M.A.M. (Eds.), Lithosphere Dynamics and Sedimentary Basins of the Arabian Plate and Surrounding Areas (Frontiers in Earth Sciences), first ed. Springer International Publishing, pp. 89-120 Ch. 5.

Russell, H., Arnott, R., nov 2003. Hydraulic-jump and hyperconcentrated-flow deposits of a glacigenic subaqueous fan: Oak ridges moraine, southern Ontario, Canada. J. Sediment. Res. 73 (6), 887-905.

Schmitz, J., Deschamps, R., Joseph, P., Lerat, O., Doligez, B., Jardin, A., 2014. From 3D Photogrammetric Outcrop Models to Reservoir Models : an Integrated Modelling Workflow.

Smith, D.P., Kvitek, R., Iampietro, P.J., Wong, K., 2007. Twenty-nine months of geomorphic change in upper monterey canyon (2002-2005). Mar. Geol. 236 (1), 79-94.

Sømme, T.O., Helland-Hansen, W., Martinsen, O.J., Thurmond, J.B., aug 2009. Relationships between morphological and sedimentological parameters in source-tosink systems: a basis for predicting semi-quantitative characteristics in subsurface systems. Basin Res. 21 (4), 361-387. http://doi.wiley.com/10.1111/j.1365-2117. 2009.00397.x.

Stevenson, C. J. a. L., Jackson, C., Hodgson, D.M., Hubbard, S.M., Eggenhuisen, J.T., 2015. Deep-water sediment bypass. J. Sediment. Res. 85 (9), 1058-1081. http:// jsedres.sepmonline.org/lookup/doi/10.2110/jsr.2015.63.

Stewart, I., 1996. Holocene uplift and paleoseismicity on the Eliki fault, western gulf of Corinth, Greece. Ann. Geofis 39 (3), 575-588.

Stewart, I., Vita-Finzi, C., jul 1996. Coastal uplift on active normal faults: the Eliki Fault, Greece. Geophys. Res. Lett. 23 (14), 1853-1856. http://doi.wiley.com/10.1029/ 96GL01595.

Storms, J.E.A., Weltje, G.J., Terra, G.J., Cattaneo, A., Trincardi, F., 2008. Coastal dynamics under conditions of rapid sea-level rise: late Pleistocene to Early Holocene evolution of barrier-lagoon systems on the northern Adriatic shelf (Italy). Quat. Sci. Rev. 27 (11-12), 1107-1123.

Stow, Dorrik A.V., Johansson, Melissa, 2000. Deep-water massive sands: nature, origin and hydrocarbon implications. Mar. Petrol. Geol. 17 (2), 145-174. https://doi.org/ 10.1016/S0264-8172(99)00051-3 ISSN 0264-8172.

Tselentis, G.-A., Makropoulos, K.C., 1986. Rates of crustal deformation in the Gulf of Corinth (central Greece) as determined from seismicity. Tectonophysics 124, 55-66.

Van Wagonier, J.C., Posamentier, H.W., Mitchum, R.M., Vail, P.R., Sarg, J.F., Loutit, T.S., Hardenbol, J., 1988. An overview of the fundamentals of sequence stratigraphy and key definitions. In: Sea-level Changes. SEPM (Society for Sedimentary Geology), pp. $39-45$. 